Article

\title{
Silica Sinter and the Evolution of Hot Springs in the Alvord/Pueblo Valleys, Southeast Oregon, USA
}

\author{
Leslie Allen Mowbray ${ }^{\dagger}$ and Michael L. Cummings * \\ Department of Geology, Portland State University, P.O. Box 751, Portland, OR 97207, USA; \\ al.mowbray@gmail.com \\ * Correspondence: cummingsm@pdx.edu \\ † Current affiliation: Metro Regional Government, 600 NE Grand Ave, Portland, OR 97232, USA.
}

Citation: Mowbray, L.A.; Cummings, M.L. Silica Sinter and the Evolution of Hot Springs in the Alvord/Pueblo Valleys, Southeast Oregon, USA. Energies 2021, 14, 7186. https:// doi.org/10.3390/en14217186

Academic Editor: Anna Sowiżdżał

Received: 10 September 2021

Accepted: 22 October 2021

Published: 2 November 2021

Publisher's Note: MDPI stays neutral with regard to jurisdictional claims in published maps and institutional affiliations.

Copyright: () 2021 by the authors. Licensee MDPI, Basel, Switzerland. This article is an open access article distributed under the terms and conditions of the Creative Commons Attribution (CC BY) license (https:// creativecommons.org/licenses/by/ $4.0 /)$.
Abstract: Hot springs in the Alvord/Pueblo valleys in southeastern Oregon are analogous to Basinand-Range hydrothermal systems where heat source and permeable pathways are met through crustal thinning. Silica sinter deposition at Mickey Springs, Alvord Valley, predates the late Pleistocene high stand of pluvial Lake Alvord. At Borax Lake, Pueblo Valley, sinter deposition occurred during the Holocene. This study examines the evolution of springs at Mickey Springs, where three morphologies of sinter are present: (1) basalt clasts surrounded by sinter in interbedded conglomerate and sandstone, (2) pool-edge and aprons of sinter surrounding depressions (12-32 m diameter), and (3) quaquaversal sinter mounds with pool-edge sinter. The oldest sinter occurs in silica-cemented conglomerate and sandstone, where deposition occurred prior to $30 \mathrm{kya}$. Deposition around broad depressions and mounds occurred after 30 kya but before water levels began to rise in pluvial Lake Alvord. Thermoluminescence dates suggest sinter deposition ceased before 18 kya when silt and clay filled inactive vents and buried aprons. A few mounds hosted active springs after sinter deposition ceased but while submerged in pluvial Lake Alvord. Now, high-temperature springs, steam vents, and mud pots are concentrated in a $50 \times 50 \mathrm{~m}$ area near the southern edge of the spring area.

Keywords: silica sinter; thermoluminescence dating; ground penetrating radar; northwestern Basinand-Range Province; Alvord/Pueblo valleys

\section{Introduction}

Surface and subsurface hydrogeological conditions of geothermal systems are recorded in silica sinters. However, the timing of sinter deposition relative to ongoing geological processes in the surrounding environment and the duration of conditions that allowed amorphous silica to be delivered to the surface environment are difficult to constrain.

Three hot spring areas in the Alvord and Pueblo valleys of southeastern Oregon (Figure 1) have silica sinter deposits, but none are currently depositing sinter. At two relatively pristine sites, Borax Lake [1-3] and Mickey Springs [4,5], stratigraphy, structure, hydrogeochemistry, and age dates provide insight into the time of silica sinter deposition during the evolution of these hot spring systems. Remote locations, designated as Area of Critical Environmental Concern (ACEC) by the Bureau of Land Management, and ownership of Borax Lake by The Nature Conservancy protect the hot spring deposits and provide opportunities to investigate the timing and duration of silica sinter deposition relative to the evolution of the geothermal systems and Late Pleistocene pluvial Lake Alvord. These temporal relations are within context of the tectonic evolution of the northwestern Basin-and-Range Province [6], ongoing deformation of the Alvord/Pueblo valleys [7-10], dynamics of fluid flow along active faults [11-15], and chronology and deformation of pluvial lake shorelines $[9,10]$. 


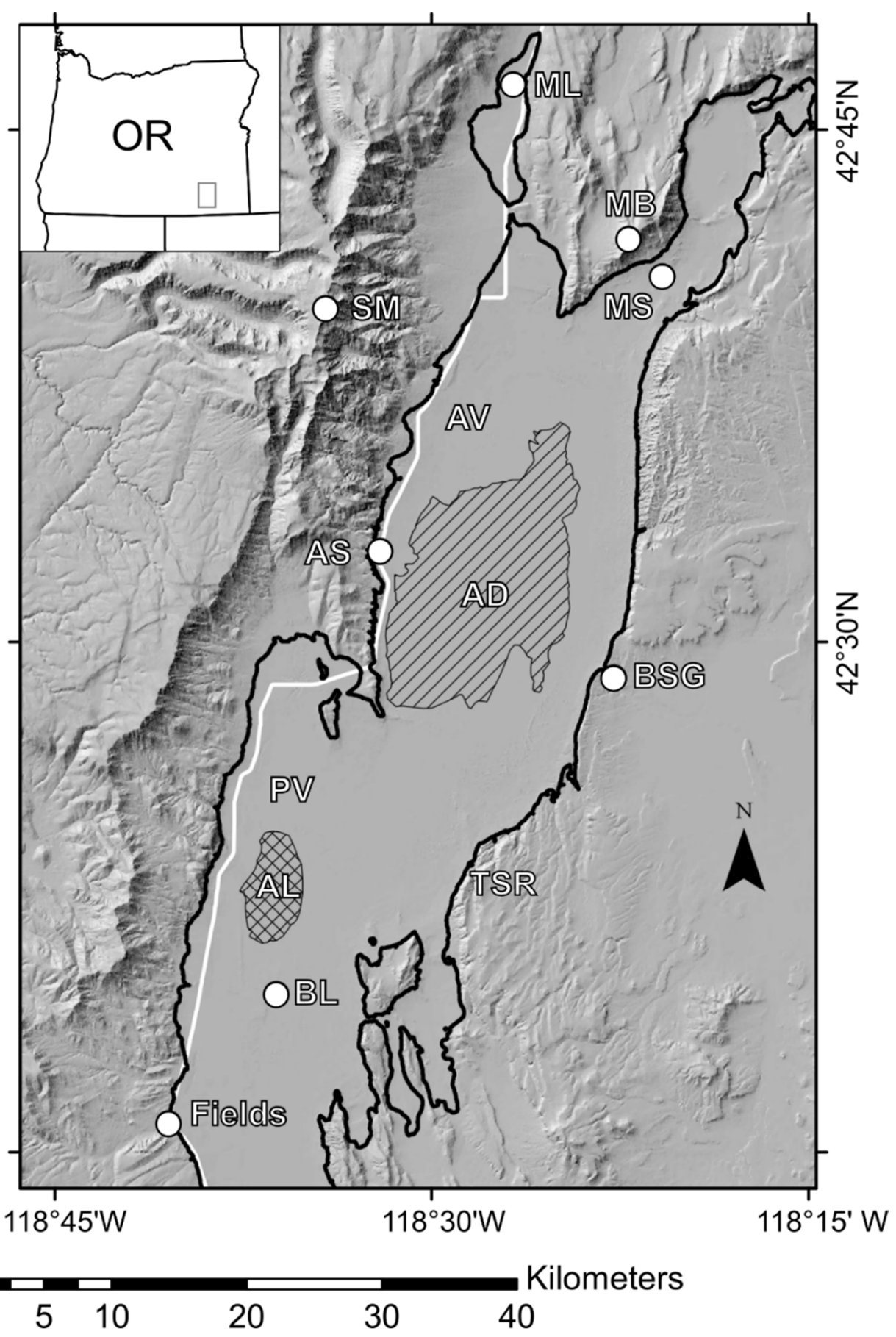

Figure 1. Location map of Mickey Springs (MS) in relation to Alvord Valley (AV) and Borax Lake in the Pueblo Valley (PV) in southeastern Oregon. High-stand elevation of pluvial Lake Alvord is outlined in black at 1292 m, before outburst flood at Big Sand Gap (BSG) in the Tule Springs Rim (TSR) lowered the lake level to $1280 \mathrm{~m}$. Fields-Denio Road represented by the white line. Alvord Hot Springs (AS), Steens Mountain (SM), Mickey Butte (MB), dry lakebed of Alvord Desert (AD, $1221 \mathrm{~m}$ ), extent of seasonally wet Alvord Lake (AL, 1227 m), Mann Lake (ML), community of Fields, Oregon, and bath house trench [8] located at Alvord Hot Springs.

While many studies have explored the micro-scale dynamics of silica sinter deposition and diagenesis (e.g., [16-19]), this study examines the meso-scale lifespan and migration of spring features at Mickey Springs. The objectives of this study were to (1) refine the stratigraphy and structure of the Mickey Springs site relative to the pluvial and neotectonic history of the Alvord/Pueblo valleys, and (2) interpret the duration and timing of sinter 
deposition from thermoluminescence dating of deposits that underlie and overlie the silica sinter deposits. These relations are compared to those at Borax Lake in the Pueblo Valley as described by $[2,3,11-13]$.

\section{Materials and Methods}

Sinter morphologies and active spring vents were mapped using a handheld GPS (Garmin GPSmap 60CSx, $\pm \sim 2 \mathrm{~m}$ ) and a Sokkia Set 4BII total station $( \pm 1 \mathrm{~cm}$, as used). Elevations were tied to USGS benchmark 28 STR (PID NX0385), with an elevation of 1247.101 m adjusted to the North American Vertical Datum of 1988.

Sinter features were measured in the north/south and east/west directions. Central depressions were measured at the slope break to the surrounding sinter apron. Apron diameters were measured where the outer extent of the sinter was apparent, or where a slope break between the edge of the apron and the surrounding landscape was observed.

Temperatures of active vents were recorded using a Vernier TMP-BTA temperature sensor with LabQuest. Thermal profiles were determined in auger holes using a custommade temperature probe controlled by an Arduino microcontroller. The temperature array consisted of 10 DS18B20 temperature sensors spaced $14 \mathrm{~cm}$ apart with insulated PVC (total of $1.5 \mathrm{~m}$ length, $1 \mathrm{~cm}$ diameter). Sensors were removed when the observed temperature variation was less than $0.5^{\circ} \mathrm{C}$ over two minutes.

Elevation modeling of the Area of Critical Environmental Concern (ACEC) and specific spring features was done using Structure from Motion (SfM). A series of photos of the spring area taken from multiple elevated positions (camera on a vertical mast and a kite and balloon with attached camera) were digitally processed using VisualSfM [20] to create an elevation point-cloud. This point cloud was imported to Meshlab [21] for removal of erroneous points, and then into CloudCompare [22] for georeferencing by visually matching GPS coordinates of photographed objects with points in the model. This georeferenced point cloud was then exported as a .las file and imported into ArcMap as a LiDAR dataset to create a digital elevation model (DEM), and a selection of the aerial images were georeferenced in ArcMap to the DEM.

Mowbray and Cummings [4] used $250 \mathrm{MHz}$ GPR and were able to resolve sinter and sedimentary structure to a $2 \mathrm{~m}$ depth. A total of three GPR transects were made in May, 2014 [5] using $50 \mathrm{MHz}$ unshielded antennas spaced $2 \mathrm{~m}$ apart operating at 1000 volts with a horizontal resolution of $50 \mathrm{~cm}$ and $17 \mathrm{~m}$ penetration depth, with one line being duplicated with $100 \mathrm{MHz}$ unshielded antennas spaced $1 \mathrm{~m}$ apart operating at 1000 volts at equal horizontal spacing and a $10 \mathrm{~m}$ penetration depth. Ground wave velocity was estimated at $0.08 \mathrm{~m} / \mu \mathrm{s}$ at the crest of feature $\mathrm{Q} 4$ with the $100 \mathrm{MHz}$ antennas by relating observed bedding changes in the exposed central depression to features in the GPR signal. Initial field observations of the GPR signal indicated penetration to $\sim 20 \mathrm{~m}$, which was used to set the time window. Each line was surveyed using a total station (Sokkia Set 4BII), and elevations were corrected to the same USGS benchmark as the surface mapping. Ekko View Deluxe [23] was used to process and visualize the GPR data.

Sediment samples were collected from surface sediments and auger holes. Thirty-two (32) samples were selected for grain size analysis: 20 samples from inside and 12 samples from outside the ACEC. Samples were wet sieved to separate pebbles $(>2 \mathrm{~mm})$ and sand $(2 \mathrm{~mm}-63 \mu \mathrm{m})$ from silts and clays $(<63 \mu \mathrm{m})$. Silt and clay are grouped here as all grains smaller than $4 \Phi(0.063 \mathrm{~mm})$. Sand-size grains are 4 to $-1 \Phi(0.063$ to $2 \mathrm{~mm})$, and pebbles range from -1 to $-6 \Phi$ ( 2 to $64 \mathrm{~mm}$ ).

Sediments for TL dating were sampled opportunistically and were not collected from specific sequence boundaries or lithology changes. Due to high ground temperatures and shallow water, table samples were collected within $1 \mathrm{~m}$ of the surface. Sample depths were reached with a $7.6 \mathrm{~cm}$ AMS hand auger. Samples for dating were collected with an AMS soil core sampler and driven with a slide hammer. The core sampler was a $12 \mathrm{~cm}$ long, $6 \mathrm{~cm}$ diameter stainless steel core cup with plastic liner. Once the sample and liner were removed from the core cup, the ends of the liner were capped and the sample inserted into 
a black PVC casing and sealed for shipping to D. Price at the University of Wollongong, Australia, for processing (Appendix A).

\section{Results}

The geothermal systems of the Alvord/Pueblo valleys evolved within the context of the structural evolution of the northwestern Basin-and-Range Province and pluvial Lake Alvord, which occupied these large grabens during the Late Pleistocene. These resources are managed within the framework of The Steens Mountain Cooperative Management and Protection Act of 2000 (Public Law 106-399).

\subsection{Geologic Setting}

Analysis of the Abert Rim fault zone (135 km west of Alvord Valley) used ${ }^{40} \mathrm{Ar} /{ }^{39} \mathrm{Ar}$ ages to constrain the timing of two major fault orientations, and applied these interpretations as a generalized structural history of the northwest portion of the Basin-and-Range Province [6]. Scarberry et al. [6] argue that the NW-striking faults formed prior to the NNE-striking range-front faults, which initiated formation of the Alvord/Pueblo valleys as grabens by normal faulting at $\sim 10$ Mya.

Steens Mountain (Figure 1) exposes the volcanic stratigraphy common in the mountains surrounding the Alvord/Pueblo valleys. The capping unit is the $1 \mathrm{~km}$-thick, Miocene age, Steens Basalt [24,25], which is underlain by older Tertiary volcanic and volcaniclastic rocks and overlain by siliceous tuff and tuffaceous sediments of Late Miocene to Early Pliocene age [26].

The Alvord Valley is bounded by generally north-northeast-striking normal faults along range fronts to the west (Steens Mountain) and east (Tule Springs Rim) (Figure 1).

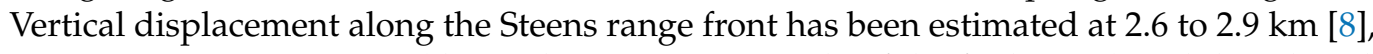
creating Steens Mountain (the upthrown western side of the fault zone) and the Alvord Valley (the eastern, downthrown side of the fault zone). Seismic profiles across the Pueblo Valley (Figure 1) show basin fill up to $800 \mathrm{~m}$ thick, and on average $500 \mathrm{~m}$ thick [27]. Vertical slip is estimated for the Alvord segment of the Steens Mountain fault zone at $0.3 \mathrm{~mm} /$ year over the last 9.3 million years [8]. East of the Alvord/Pueblo valleys, the Sheepshead and Trout Creek mountains bound the valley with north-striking, west-dipping normal faults of a lower slip rate and approximate equal age. Singleton [9] and Oldow and Singleton [10] documented Holocene fault movements up to $4 \mathrm{~mm} /$ year, indicating continued fault movement into present time. Oldow and Singleton [10] also estimated that $50 \%$ of total east/west extension across the Alvord Valley has occurred on the Steens Mountain rangefront faults, $20 \%$ has happened on the eastern margin of the valley, and 30\% across the basin floor in faults hidden by basin fill.

Conventional geothermal systems have three requisite components: (1) a heat source, (2) a water source, and (3) permeable zones to allow water circulation. Numerical models describing the inter-relations among these components have been developed by Wisian and Blackwell [28] and McKenna and Blackwell [29] for extensional geothermal systems of the Basin-and-Range Province. In the Alvord/Pueblo valleys, the heat source is provided by the steepened thermal gradient associated with crustal extension in the northwestern Basin-and-Range Province (e.g., [6,30,31]). Oxygen/hydrogen isotopes are consistent with meteoric water $[1,2,32]$ recharged from the Steens Mountain fault block. Permeable zones for circulation of heated water are provided by active deformation along fault systems within the Steens Mountain/Alvord Valley system [8,10,12,13,15].

\subsection{Pluvial Lake Alvord}

Late Pleistocene lakes, including pluvial Lake Alvord, were widespread in the Basinand-Range Province. Sparse datable materials in the Alvord/Pueblo valleys forces a reliance on studies in neighboring basins to reconstruct the Pleistocene history. Benson and Thompson [33] reported lake levels for Lake Lahontan, the most studied lake $15 \mathrm{~km}$ to the south, dating back to $50 \mathrm{kya}$. They showed a gradual deepening of the lake until $15 \mathrm{kya}$, 
and a sharp increase in the lake level lasting from 15-12 kya, after which the lake quickly dried. Many of these pluvial lakes, including Lake Lahontan, may have had a dry period of little or no standing water from 35-20 kya [34].

Pleistocene pluvial Lake Alvord formed wave-cut terraces in the Alvord/Pueblo valleys that are summarized by Oldow and Singleton [10]. Their study grouped central Alvord Valley paleoshorelines into older Serrano terraces (elevation from 1320 to $1280 \mathrm{~m}$ ) and younger Alvord terraces (elevations from 1294 to $1256 \mathrm{~m}$ ), both of which have been offset by faults. The ages of the three older Serrano terraces are estimated by correlation with the better-studied Eetza highstand of Lake Lahontan, and loosely constrained between 200 and 130 kya [35].

Age estimates of the younger Alvord terraces vary (e.g., [10,36]). The age of the highest shoreline of the Alvord terraces is constrained by luminescence dating of shorelines in Bog Hot Valley [37] as $17.8 \pm 1 \mathrm{kya}$. The lake level may have retreated to as low as $15 \mathrm{~m}$ above the floor of the Alvord Valley by 10-12 kya, as determined through arrowhead analysis at archaeological sites [38].

At least one episode of a rapid lake-level decrease has been documented [36] when the lake overtopped Big Sand Gap (Figure 1). The overtopping water incised Big Sand Gap from 1292 to $1280 \mathrm{~m}$, draining $11.3 \mathrm{~km}^{3}$ of water to the east and into Coyote Basin, eventually draining into the Owyhee River. Chemical correlation of an ash layer at $1243 \mathrm{~m}$ with deposition of Mt. St. Helens ash (set Sg tephra, age of 13-14 kya) suggests deep-water conditions at the time of deposition, but it is not determined by the authors if it was deposited before or after the overtopping and incision, which lowered the lake level to $1280 \mathrm{~m}$.

Archaeological evidence from Alvord Valley indicates a pattern of drying through the Holocene. After a possible lake-level minimum at around 11.5 kya [39], basin lakes are known to have been habitation centers for native people. The Western Pluvial Lakes Tradition [40] was marked by continuous habitation around pluvial lakes from 9 to 5 kya. Beck [41] argues that the period from 5 to 3 kya saw location-dependent alternating periods of wet and dry in eastern Oregon with shallow lakes or seasonal wetlands occupying the valleys of the former deeper pluvial lakes. Today, the Alvord Desert is the driest area in Oregon, receiving less than $17 \mathrm{~cm}$ of precipitation a year [42].

\subsection{Mickey Springs}

The Alvord Valley bifurcates to the north with a western fault-bounded valley along the Steens Mountain front and an eastern fault-bounded valley, which extends with a north/northeast trend to Mickey Basin (Figure 2). The horst block between the two valleys includes Mickey Butte, which lies northwest of Mickey Springs. 


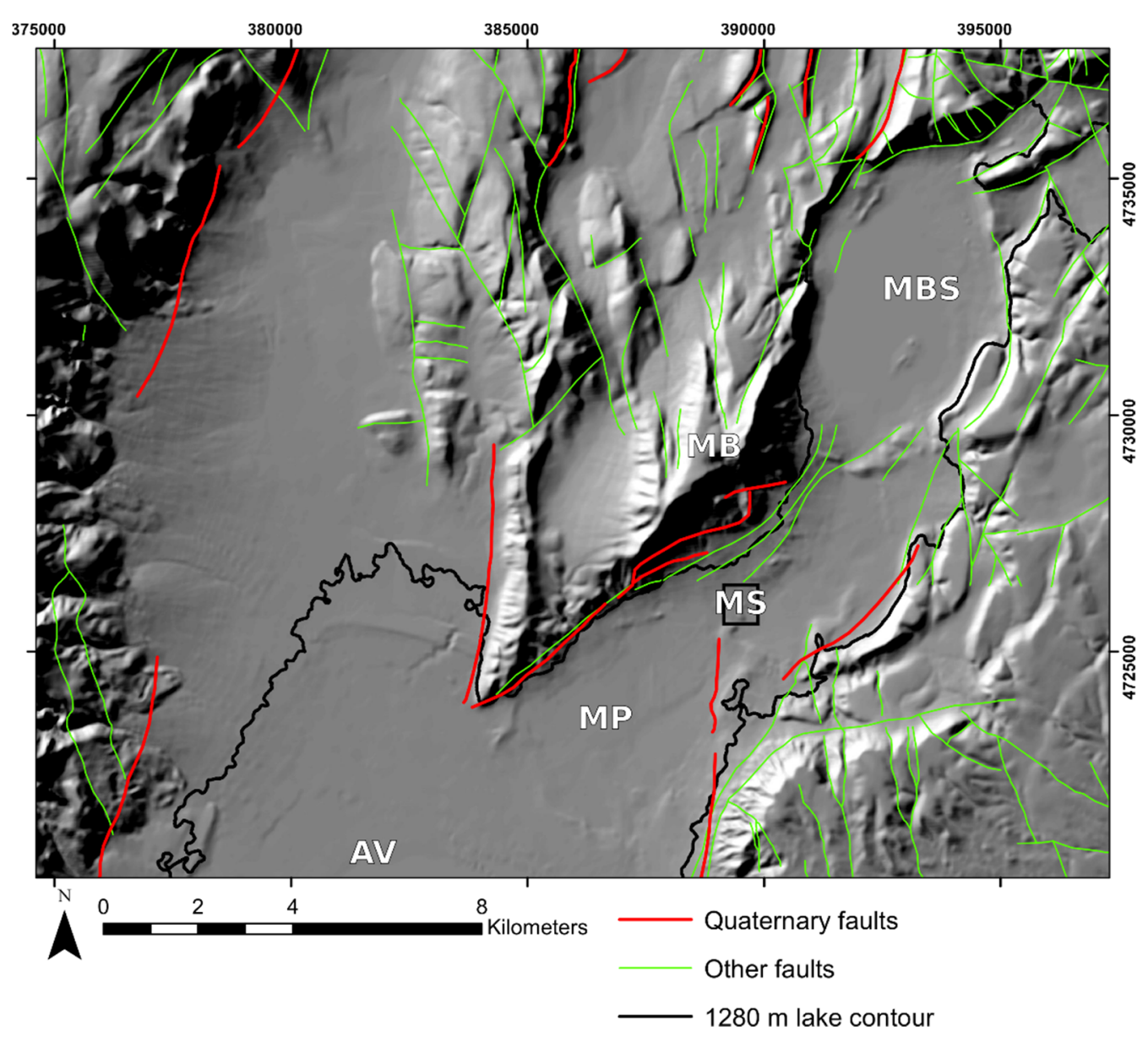

Figure 2. Mickey Basin (MBS) is a sub-basin extending to the NE from the Alvord Valley (AV). Mickey Butte (MB) is part of the horst block that separates the two arms of the Alvord Valley. Mickey Springs (MS) is directly southeast of Mickey Butte. A third sub-basin, here called Mickey playa (MP), is southwest of Mickey Springs. Several Quaternary faults have been mapped (red lines), and some have offset shorelines from pluvial Lake Alvord (1280 m shoreline indicated by black line). Several other faults have been mapped in the vicinity of varying age (green lines). Fault data are from [43,44].

Mickey Springs, Borax Lake, and Alvord Hot Springs (Figure 1) are in the Alvord Valley Known Geothermal Resource Area (KGRA). Anadarko Petroleum Company announced the discovery of a thermal aquifer in a 451-m-deep exploration well located $2.3 \mathrm{~km}$ southwest of Borax Lake (press release 7 November 1989) in the Pueblo Valley. The well was flow tested for $22 \mathrm{~h}$ and yielded flow rates of $1500 \mathrm{Lm}^{-1}$ with temperature measured at $152{ }^{\circ} \mathrm{C}$. The discovery well was within an ACEC designated by the Bureau of Land Management (BLM) in 1983. The ACEC adjoins 65 hectares including Borax Lake owned by The Nature Conservancy to protect the habitat of the endemic Borax Lake chub (Gila boraxobius). Anadarko Petroleum Company dropped leases on public land in December 1996. The legal status of the chub was reviewed by Echelle and Echelle [45]. The Steens Mountain Cooperative Management and Protection Act of 2000 (Public Law 106-399) declared the Alvord Valley KGRA off limits for geothermal development. As part of the agreement, Mickey Springs in the Alvord Valley was designated an ACEC inside a Wilderness Area on public land managed by the BLM. Alvord Hot Springs is located on private land but has seen limited development for recreational purposes.

The relatively pristine Mickey Springs consists of a tight cluster of active and inactive springs in an area smaller than 4 hectares. Over 50 active vents are present at Mickey Springs. While several high-temperature mud pots and steam vents are currently active, only one spring's outflow is near boiling $[1,2,46]$. Other lower-temperature springs 
$\left(30-60{ }^{\circ} \mathrm{C}\right)$ are present and have a visually estimated combined outflow volume less than the single high-temperature area.

Oestreicher [46] studied the micro-scale textures of pool edge sinter at Mickey Springs and compared them to current microbial colonies in spring outflow channels. He determined the outflow fluid temperatures at the time of sinter deposition to be $40-60{ }^{\circ} \mathrm{C}$, and supersaturated with amorphous silica. This silica precipitated from the thermal water onto the microbial communities present at the time, preserving the texture of the silicified microfossils.

Nicholson et al. [47] analyzed the microcrystaline structure of silica sinter at Mickey Springs and Borax Lake. The samples analyzed from Borax Lake were predominantly amorphous silica (opal-A), while the silica sinter at Mickey Springs has a significant portion of paracrystaline silica (opal-CT). As both spring systems have similar water chemistry, the primary deposits of silica were assumed to be amorphous, with the transition to the microcrystalline structure taking place over time after deposition. This led the authors to conclude, based on the silica phase, that the sinter at Mickey Springs was older (up to 30 kya) than at Borax Lake (4 kya).

Anderson and Fairley [15] modelled the heat flux at Mickey Springs using temperature probes to assess the structural context of the spring system. Their work sought to classify the type of structural setting for the springs based on the conceptual models of Curewitz and Karson [48] and favored a model of interacting fault tips, with areas of shear and extension. Further, the authors compared this finding to an unpublished fault map (Figure 3) of the Mickey Springs area by J.S. Oldow (unpublished data, 2006). The authors correlated the areas of high heat flux to the areas of extension expected in a releasing fault step. At Borax Lake, the 100+ springs north of the lake are categorized as fault trace hot springs and geothermal fluid flow in this setting was investigated by Fairley et al. [11] and Fairley and Hinds $[12,13]$.

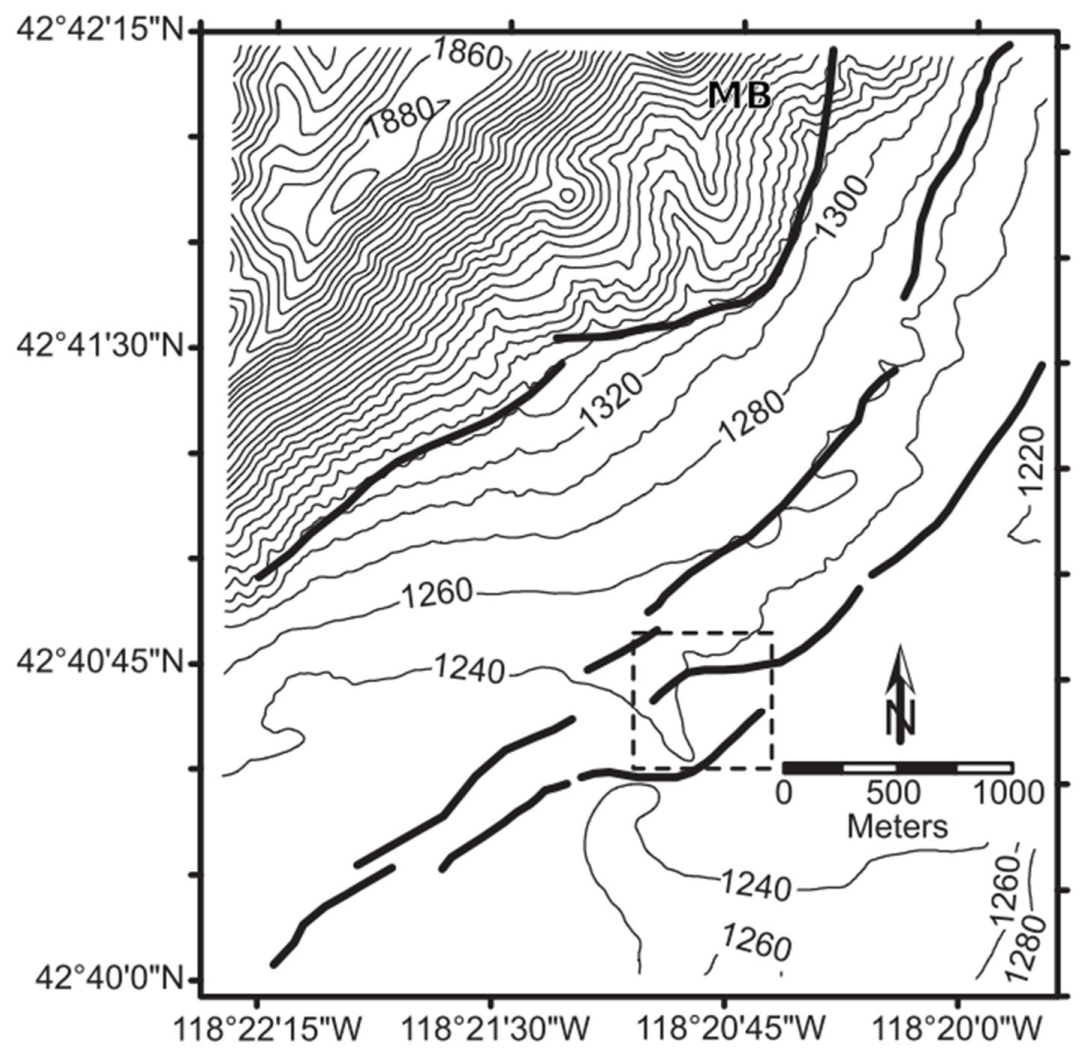

Figure 3. Topographic map and inferred locations of faults of Mickey Springs area as mapped by J.S. Oldow (unpublished data from 2006, fide [15]). Dashed box is the study area of Anderson and Fairley [15], and the approximate extent of the current study. 
Cummings and St. John [2] determined that fluids from the three major hydrothermal systems in the Alvord and Pueblo Valleys (Alvord Hot Springs, Borax Lake, and Mickey Springs) are meteoric in origin. They estimated a minimum aquifer temperature for Mickey Springs of $168{ }^{\circ} \mathrm{C}$ based on oxygen-sulfate isotope geothermometry. The ${ }^{87} \mathrm{Sr} /{ }^{86} \mathrm{Sr}$ ratios of thermal water and bedrock units suggest the thermal aquifer is stratigraphically beneath Steens Basalt in the Steens Mountain volcanics at a depth of 1 to $2 \mathrm{~km}$. The estimated minimum reservoir temperature for the aquifer feeding springs north of Borax Lake is $203{ }^{\circ} \mathrm{C}$. The ${ }^{87} \mathrm{Sr} /{ }^{86} \mathrm{Sr}$ ratios for springs north of Borax Lake are consistent with deeperseated welded tuff and basalt $[1,2,49]$.

Silica sinter at Mickey Springs occurs in three morphologies: (1) mounds with narrow central depressions, (2) broad depressions, and (3) sinter-bearing silica-cemented sandstone and conglomerate. The distribution of these morphologies is presented in Figure 4.

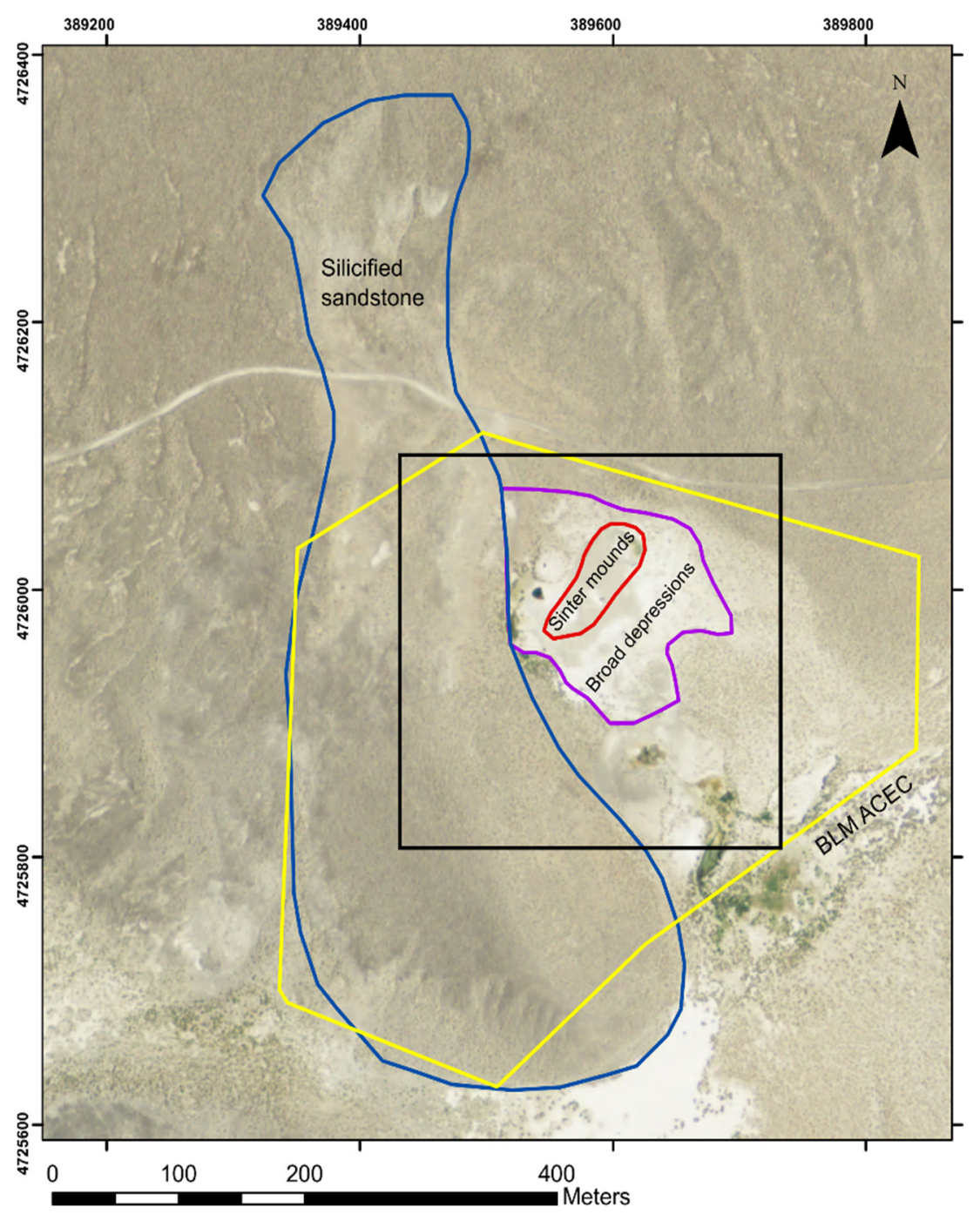

Figure 4. Three morphologies of sinter were identified at Mickey Springs: (1) sinter aprons surrounding narrow depressions (outlined in purple); (2) sinter-rimmed broad depressions blanketed with loose fine-grained sediment (outlined in red); and (3) silica-cemented conglomeratic to fine-grained sandstone (outlined in solid blue). Black box indicates the outline for Figure 5. Yellow line indicates the extent of Area of Critical Environmental Concern (ACEC) managed by BLM. 


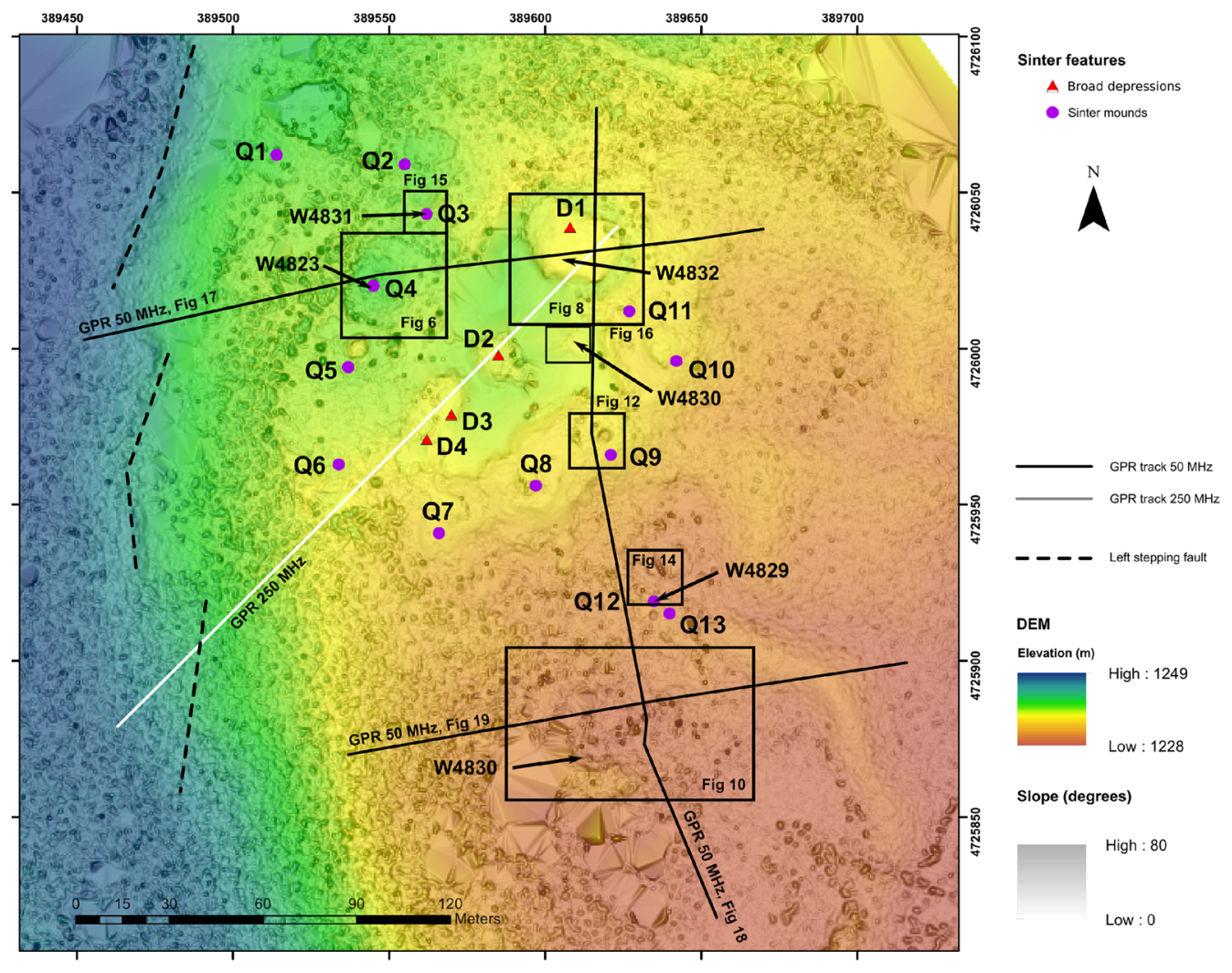

Figure 5. Sinter mounds (purple O) and broad shallow depressions (red triangle). The more southern of these features $(\mathrm{Q} 7, \mathrm{Q} 8, \mathrm{Q} 10)$ have asymmetric aprons that dip south with topography. GPR track from December, 2013 [4] shown in white, and tracks from May, 2014 (current study) are shown as a solid black line. Surface morphology and the elevation model suggest a left-stepping fault striking N-NE (dashed line).

\subsubsection{Mounds with Narrow Depressions}

Several mounds with pool-edge sinter and quaquaversal aprons lie on a topographic bench between 1235 and $1240 \mathrm{~m}$ (Figure 5). The more southern of these typically have aprons elongated along the south-dipping slope toward the lower-elevation hightemperature spring area $(\mathrm{Q} 7, \mathrm{Q} 8, \mathrm{Q} 10)$. Brief descriptions are provided in Table 1.

Table 1. Descriptions and elevations of broad depressions (e.g., D1) and sinter mounds (e.g., Q1) at Mickey Springs.

\begin{tabular}{|c|c|c|c|c|}
\hline & Description & $\begin{array}{c}\text { Surveyed } \\
\text { Elevation }(\mathrm{m})^{1}\end{array}$ & $\begin{array}{c}\text { Depression } \\
\text { Diameter (m) }\end{array}$ & $\begin{array}{c}\text { Interior Vertical } \\
\text { Relief (m) }\end{array}$ \\
\hline D1 & $\begin{array}{l}\text { Largest diameter depression in ACEC. Fine grained } \\
\text { sediment common in depression floor, with blocks of } \\
\text { sinter exposed in rim and collapsed blocks on } \\
\text { depression floor. Two vegetated areas are present in } \\
\text { eastern portion of depression, where two springs with } \\
\text { no visible outflow are present. Seven other springs or } \\
\text { steam vents are present in depression floor. } \\
\text { Temperatures of active springs range from } 38.6 \text { to } \\
72.5^{\circ} \mathrm{C} \text {. }\end{array}$ & 1236.72 & 32.05 & 1.77 \\
\hline D2 & $\begin{array}{l}\text { Broad depression with floor of moderately sorted silt } \\
\text { and clay with clasts of sinter. Mound of sinter at center } \\
\text { of depression protruding from sediment with }<10 \mathrm{~cm} \\
\text { relief. Extent of depression marked by slope break } \\
\text { coincident with transition to exterior blanket of } \\
\text { well-sorted silt and clay. }\end{array}$ & 1237.63 & 21.25 & 0.93 \\
\hline
\end{tabular}


Table 1. Cont.

\begin{tabular}{|c|c|c|c|c|}
\hline & Description & $\begin{array}{c}\text { Surveyed } \\
\text { Elevation (m) }\end{array}$ & $\begin{array}{c}\text { Depression } \\
\text { Diameter }(m)^{2}\end{array}$ & $\begin{array}{c}\text { Interior Vertical } \\
\text { Relief }(\mathrm{m})^{1}\end{array}$ \\
\hline D3 & $\begin{array}{l}\text { Two overlapping depressions, both with sinter blocks } \\
\text { exposed in depression floor. No sinter is exposed in } \\
\text { walls of the depression. Slope break at edge of } \\
\text { depression floor consistent with transition to uniform } \\
\text { exterior blanket of fine-grained silt and clay. }\end{array}$ & 1237.12 & 19.55 & 1.13 \\
\hline & & $\begin{array}{l}\text { mean } \\
\text { sdv }\end{array}$ & $\begin{array}{c}21.13 \\
8.40\end{array}$ & $\begin{array}{l}1.10 \\
0.50\end{array}$ \\
\hline
\end{tabular}

Sinter apron around slight depression of loose sediment. Apron slopes to the east, and is not apparent west of the depression, where slope increases toward the topographic ridge and sandstone outcrop west of spring area.

Q2 Extensive sinter apron around slight depression of loose sediment with blocks of broken sinter.

Extensive sinter apron around area of loose sediment

Q3 and blocks of broken sinter. Pool edge sinter exposed around area of loose sediment.

Quaquaversal sinter apron with deep central depression. Vertical exposure in depression exposes $90 \mathrm{~cm}$ of pool edge sinter above $110 \mathrm{~cm}$ of laminated sinter interbedded with coarse sand and silicified root casts. Lower throat of depression broadens, and depression floor consists of loose, poorly sorted sand and silt with blocks of pool edge sinter up to $1.5 \mathrm{~m}$ collapsed from apron above.

Active spring pool with visually estimated $5 \mathrm{~m}$ of vertical relief visible in pool. Near horizontal sinter apron present around spring pool.

Quaquaversal sinter apron around slight depression. Outflow channel from Q5 passes west and south of apron. Apron more extensive to south and east of depression, following slope of local topography.

Sinter apron surrounding slight depression of loose sediment. Depression is near northern extent of apron, and apron slopes away to south and east with local topography.

Sinter apron exposed in half-circle on southern portion, dipping away with local topography. Flat area of loose poorly sorted sand and sinter clasts inside radius of pool edge sinter. Mound of loose well-sorted silt and clay in center of flat area.

Sinter apron around central depression. Active spring pool with cloudy brown water and green microbial mats covers $1 / 4$ of depression floor. Inward-dipping pool edge sinter overhangs pool in depression. In March 2014, sinter apron was exposed, and in May 2014 was coated by $13 \mathrm{~cm}$ of moderately sorted silt and clay erupted from the depression spring pool.

Extensive sinter apron forming complete cap with no central depression, but thickness of sinter $(0.4 \mathrm{~m})$ is exposed by collapsed block, which reveals open space extending for $2.8 \mathrm{~m}$ laterally and $0.6 \mathrm{~m}$ vertically between the bottom of the sinter apron and a base of fine-grained sediment and sinter blocks. 
Table 1. Cont.

\begin{tabular}{|c|c|c|c|c|}
\hline & Description & $\begin{array}{c}\text { Surveyed } \\
\text { Elevation }(\mathrm{m}){ }^{1}\end{array}$ & $\begin{array}{c}\text { Depression } \\
{\text { Diameter }(m)^{2}}^{2}\end{array}$ & $\begin{array}{c}\text { Interior Vertical } \\
\text { Relief (m) }\end{array}$ \\
\hline Q11 & $\begin{array}{l}\text { Circular sinter apron with central depression. Sinter } \\
\text { apron exposed and broken in blocks, with no sediment } \\
\text { blanket coating the apron. }\end{array}$ & 1236.58 & 3.00 & 0.19 \\
\hline Q12 & $\begin{array}{l}\text { High-relief sinter apron with exposed pool-edge sinter } \\
\text { surrounding small depression. Sediment in depression } \\
\text { was poorly sorted silt up to } 4 \mathrm{~cm} \text { clasts of sinter. A } \\
\text { fracture in the sinter apron extends N/NE from the } \\
\text { depression. Water is present in fracture approximately } \\
50 \mathrm{~cm} \text { below ground surface, and depression sediment } \\
\text { temperature is } 59^{\circ} \mathrm{C} 27 \mathrm{~cm} \text { below the surface of the } \\
\text { depression floor. }\end{array}$ & 1231.57 & 3.60 & 1.30 \\
\hline \multirow[t]{2}{*}{ Q13 } & $\begin{array}{l}\text { Small active spring pool rimmed with sinter apron. No } \\
\text { current outflow but visible established outflow } \\
\text { channel into depression of Q12. Spring vent in center } \\
\text { of central spring pool. }\end{array}$ & 1232.11 & 1.00 & $\mathrm{n} / \mathrm{a}$ \\
\hline & & $\begin{array}{c}\text { mean } \\
\text { sdv }\end{array}$ & $\begin{array}{l}5.06 \\
4.18\end{array}$ & $\begin{array}{c}0.44 \text { * } \\
0.42\end{array}$ \\
\hline
\end{tabular}

\footnotetext{
${ }^{1}$ Elevations measured with Sokkia Set 4 BII total station $( \pm 1 \mathrm{~cm}) .{ }^{2}$ Pool dimensions measured by a tape measure $( \pm 1 \mathrm{~cm})$ on the east-west and north-south axis. * mean excludes vertical relief of $\mathrm{Q} 4$.
}

Many of the sinter mounds have narrow shallow central depressions, but some have no identifiable central depression. Feature Q4 (Figure 5) has typical morphology but is unique in that it has over $3 \mathrm{~m}$ of relief in the central depression (Figure 6). The central depression is rimmed with inward-dipping pool-edge sinter from the highest point on the sinter apron down to $90 \mathrm{~cm}$ within the vertical wall of the depression. Below this, laminar sinter is exposed from $90 \mathrm{~cm}$ to $2 \mathrm{~m}$. Moderately sorted, subangular to rounded, coarse-grained sand is present between sheets of sinter, and silicified root casts are common. Below the laminar sinter, un-cemented, moderately sorted, subangular to rounded, coarsegrained sand is exposed (Figure 6,1A-DT). Silicified root-casts are also present in this sediment down to $2.9 \mathrm{~m}$. The depression widens below $2 \mathrm{~m}$ and some cavities extend at least $2 \mathrm{~m}$ horizontally under the laminar sinter and above the floor of the depression (see Figure $6 \mathrm{c}$ ). The sediment below $2.9 \mathrm{~m}$ is well sorted, subrounded to rounded fine-grained sand and silt (Figure 6, 1C-DT). A large block of pool-edge sinter, broken from the rim, lies on the floor of the depression.

\subsubsection{Broad Depressions}

Several broad depressions are present in the ACEC (Figures 5 and 7). The largest of these features, D1, has pool-edge sinter exposed around much of the rim surrounding the depression (Figure 8). These depressions are 12 to $32 \mathrm{~m}$ in diameter, with an average depth of $1.1 \mathrm{~m}$. The depressions are aligned $\mathrm{E} / \mathrm{NE}$ at an elevation of $1237 \mathrm{~m}$. The floors of the depressions are typically dry loose sediment, but blocks of sinter up to $1 \mathrm{~m}$ are present in some. A $0.6 \mathrm{~cm} \times 1.5 \mathrm{~m}$ metal rod was used to probe the subsurface to identify areas of loose sediment (rod will penetrate when pushed by hand) and sinter (rod will not penetrate). Probing in the depression floor varied from smooth to gritty-sounding and easily inserted, to meeting refusal at as little as a few centimeters below the surface. In areas of the rim where sinter is exposed, probing laterally with a metal rod beneath the sinter is able to penetrate to the length of the rod. The sinter apron here does not have great vertical thickness but overlies loose sediment in a similar stratigraphic relation as exposed in the depression of feature Q4 (Figure 6). 


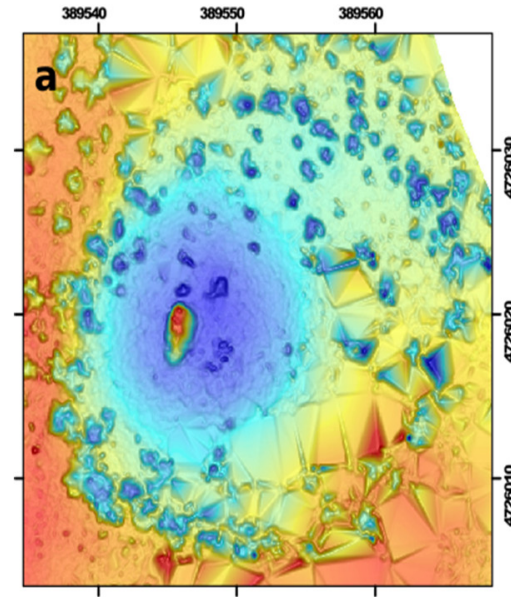

DEM

Elevation $(m)$

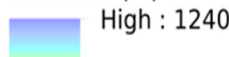

Low : 1238

Slope
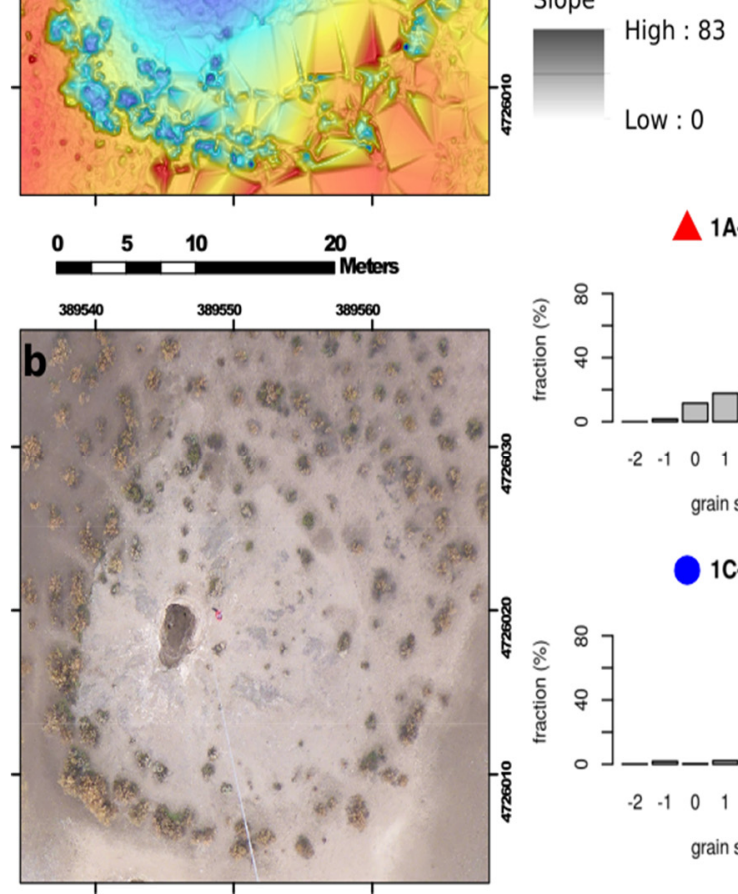
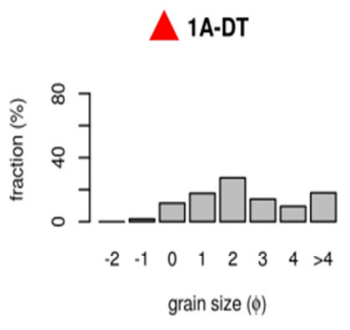

1C-DT

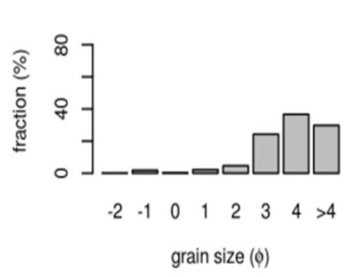

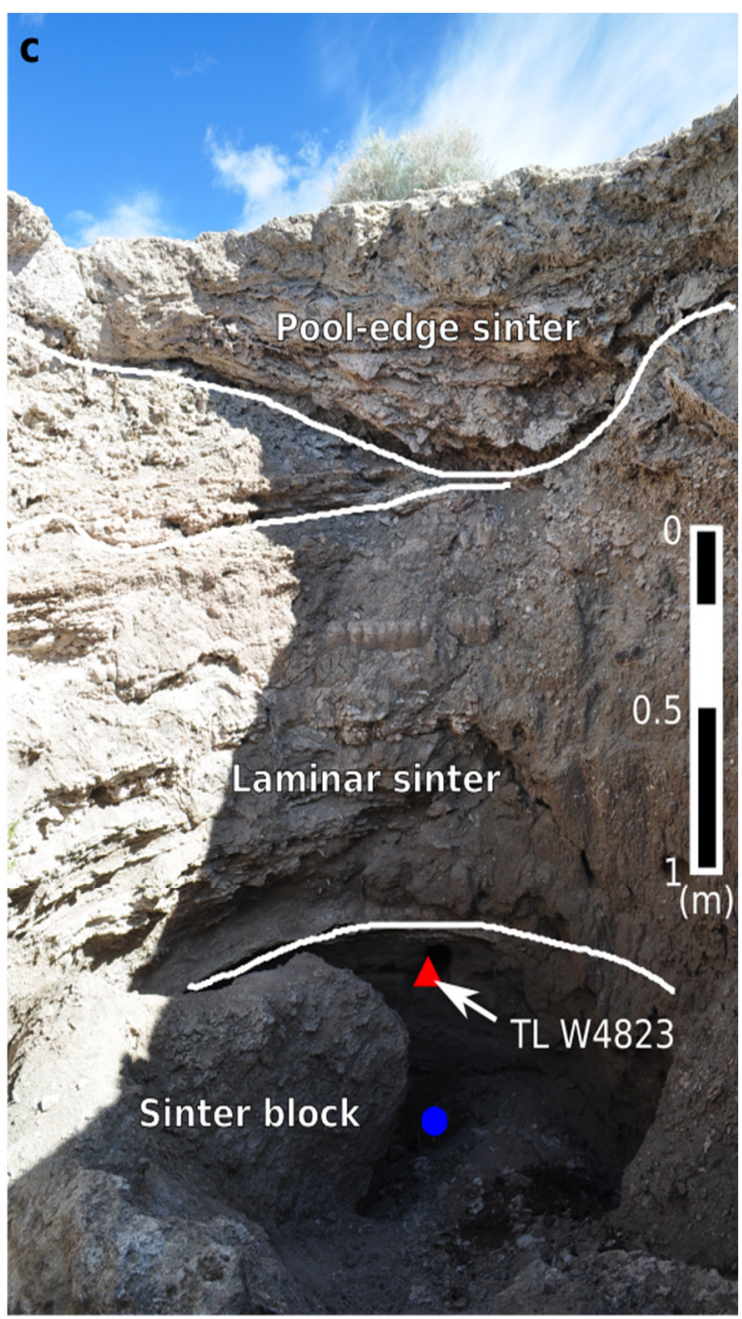

Figure 6. (a) Elevation model of the sinter apron of feature Q4 with a draped slope map to show detail. (b) Georeferenced aerial photo of feature Q4 at the same extent as (a). (c) Stratigraphy exposed in the central depression of feature Q4, looking north while standing on the floor of the central depression. Inward-dipping pool-edge sinter is exposed at the surface down to $90 \mathrm{~cm}$. Laminar sinter interbedded with un-cemented coarse-grained sand is present from $90 \mathrm{~cm}$ to $2 \mathrm{~m}$. Silicified root-casts are present between layers of laminar sinter and in underlying coarse-grained sand to $2.9 \mathrm{~m}$. Location of the TL sample W4823 indicated by an arrow. Grain size charts of two sediment samples are shown in the center of the image, with the sample location indicated by the corresponding colored symbols.

Sediments in the depression floor are fine-grained silt and clay with blocks of pooledge sinter and silicified root casts (Figure 9c). The ground surface is often crunchy underfoot when dry but makes a thick sticky mud when moistened by precipitation. A sample was collected from the surface in dry conditions from a thin $(<1 \mathrm{~cm})$ crust dissolved in $\mathrm{HCl}$. This crust overlies loose powdery silt and clay. An auger was used to sample sediments in the southwest part of the depression, where probing with the metal rod met no refusal. The sediment was reassembled for the photo in Figure 9d. The top $27 \mathrm{~cm}$ consisted of 70\% well-sorted brown silt and clay. The coarse portion (larger than fine sand) of the near-surface sediment was composed primarily $(60 \%)$ of angular to rounded sinter fragments that did not effervesce with $\mathrm{HCl}$ (Figure 9b). Fragments of root casts were also common in the coarse portion (40\%). Both the root and sinter fragments are coated by carbonate, which dissolves in $\mathrm{HCl}$. Less than $1 \%$ of this sample comprised lithic fragments. 


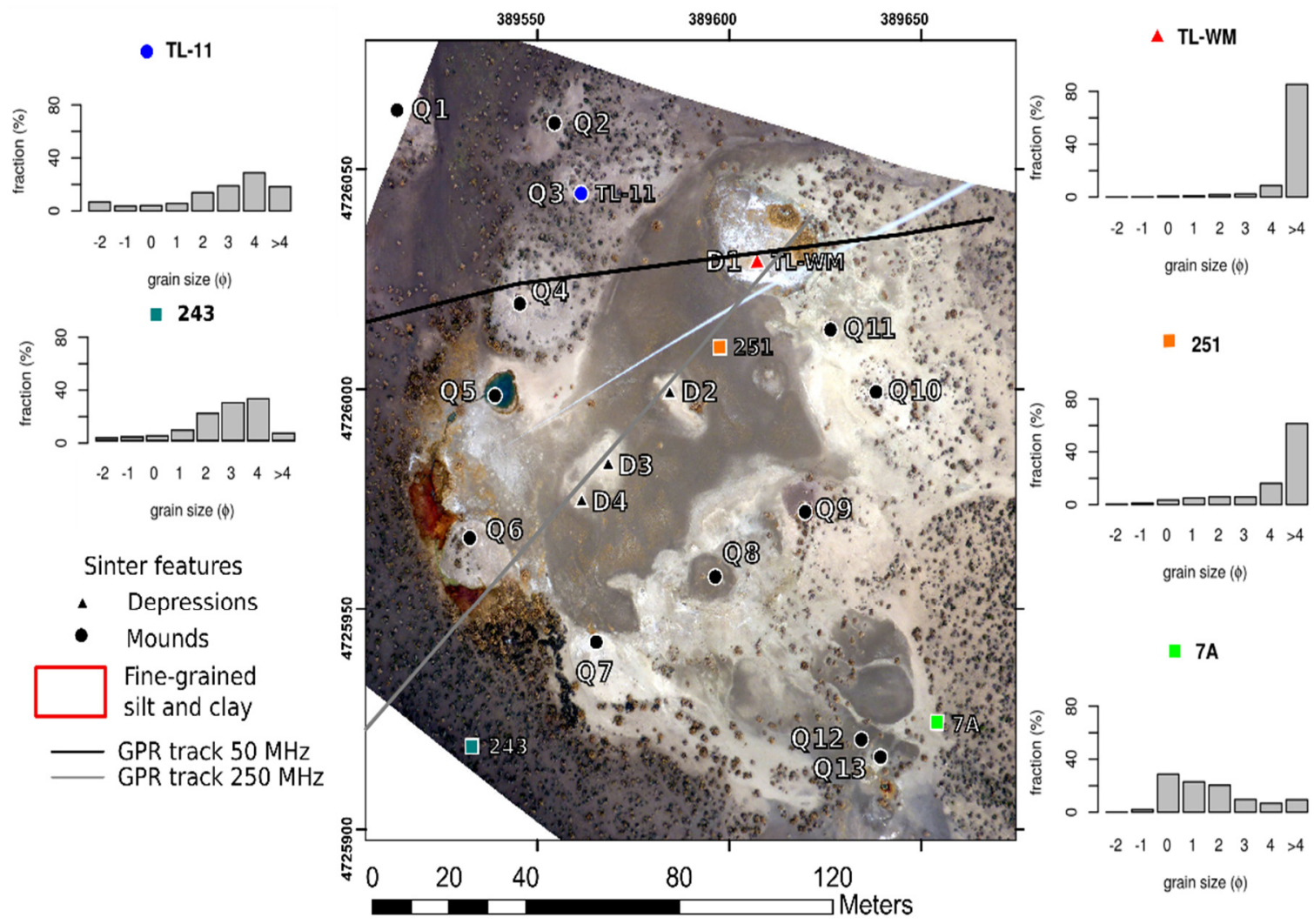

Figure 7. Area of sinter mounds and broad depressions. The aprons surrounding broad depressions are blanketed with silt and clay (gray area) that effervesces with $\mathrm{HCl}$. White areas in the photo are exposed sinter or broken sinter gravel and sediment. Typical sediment outside of this area is poorly sorted coarse- to fine-grained sand (blue, teal, and green dots).
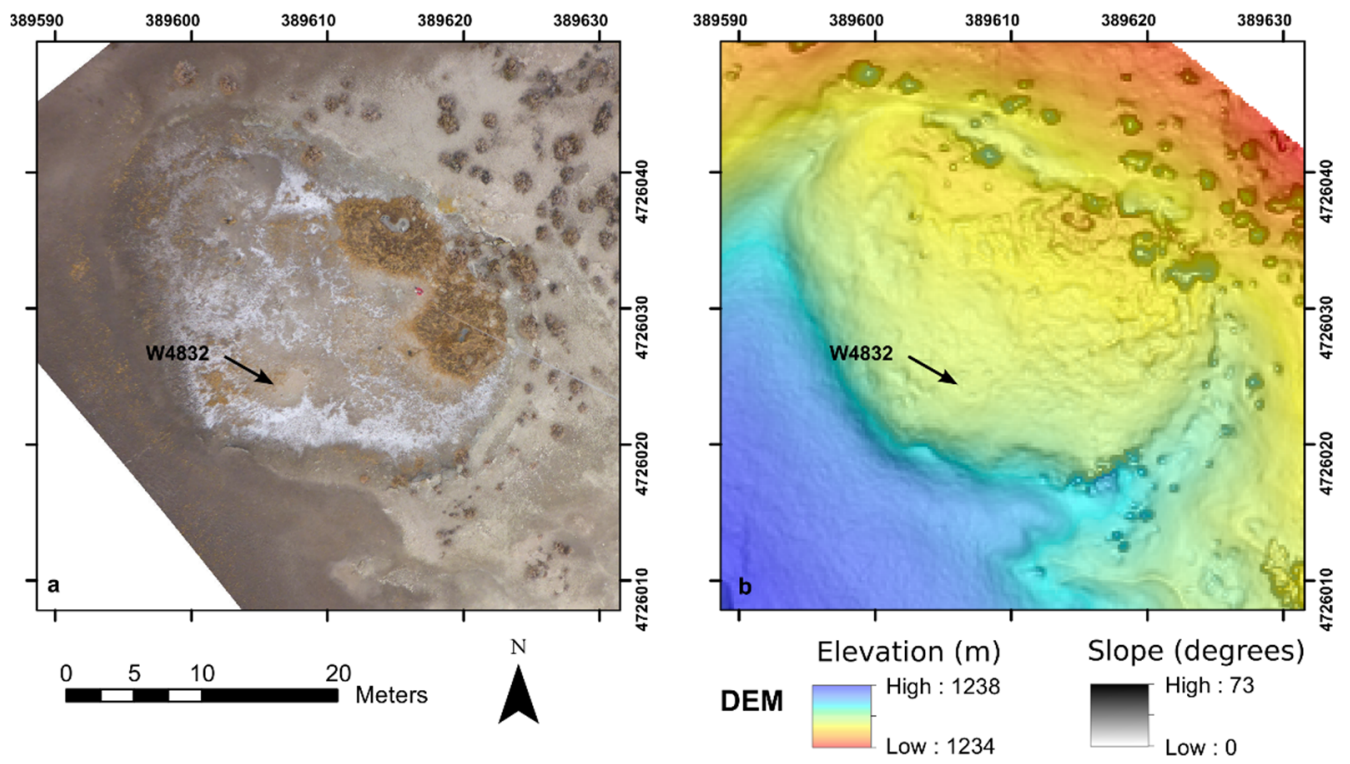

Figure 8. (a) Aerial photo of the broad depression of feature D1. (b) Elevation model of feature D1 showing a relatively sharp interior slope of the depression. Apron surrounding the depression gradually slopes away from the depression where sinter is exposed (northeast portion) and is relatively horizontal where blanketed with fine-grained silt and clay (southwest portion). Pool-edge sinter outcrops at high-slope areas around the edge of the depression. 


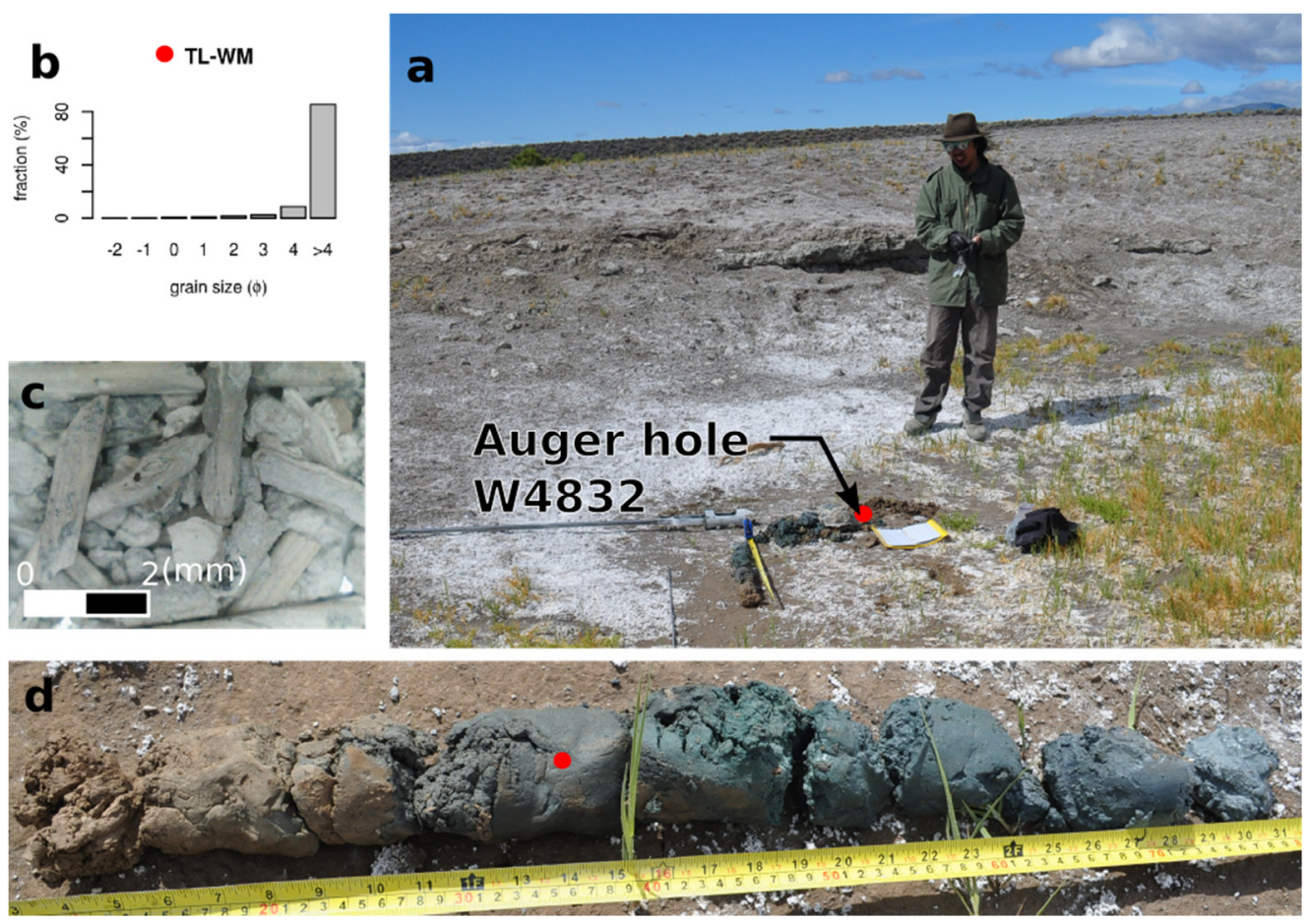

Figure 9. (a) Looking west toward sandstone ridge (distant vegetated ridge) from depression D1. Auger hole for the TL sample W4832 is in loose sediment in the depression floor (red dot). Sinter outcrop is visible halfway up the rim around the central depression. Sinter surrounding the depression is blanketed with loose fine-grained sediment. (b) Grain size analysis for the sediment sample collected from $20 \mathrm{~cm}$ below the surface, and immediately above the TL sample. (c) Root fragments and silica sinter from the coarse portion of sediment collected from the surface of D1. (d) Reconstructed soil column from the auger hole in D1. Surface sediments (left) were loose sand and silt with fragments of sinter and roots. Grain size decreased with depth, while sorting increased. Approximate TL sample depth indicated by the red dot.

Grain size decreased with depth, while uniformity and rounding of grains increased down to $40 \mathrm{~cm}$. Below $40 \mathrm{~cm}$, sediment was $85 \%$ well-sorted green silt and clay, which did not react with $\mathrm{HCl}$ (Figure 9b). Sand grains are subrounded to rounded. The coarse portion was $80 \%$ sinter and $20 \%$ lithic fragments (mostly basalt), and the lithic and crystal content increased to $50 \%$ of the total at the finest sand-grain sizes. This auger hole was dug to $113 \mathrm{~cm}$, where the sediment was saturated and too fine grained to be brought up in the auger. The water table was at $35 \mathrm{~cm}$. The temperature probe was inserted into the auger hole, and pushed easily further into the saturated soil to a total depth of $165 \mathrm{~cm}$. Soil temperature increased with depth, from $28^{\circ} \mathrm{C}$ at $40 \mathrm{~cm}$ to $47^{\circ} \mathrm{C}$ at $165 \mathrm{~cm}$.

Sinter is seldom exposed in the higher ground surrounding the depressions. Instead, the sinter aprons are buried by loose fine-grained well-sorted silt that effervesces with $\mathrm{HCl}$. The coarse-grained portion contains primarily rounded sand-size grains of sinter. The extent of the silt is indicated in Figure 7. The sediment blanket was probed with a metal rod to depths up to $1.5 \mathrm{~m}$ before meeting refusal. Sediments outside the area of blanketing silt are typically poorly sorted coarse- to fine-grained sand (Figure 7).

\subsubsection{Conglomerate Cemented with Silica Sinter}

Silica-cemented sandstone and conglomerate crops out in the area shown in Figure 4. The location of a topographic ridge oriented roughly $\mathrm{N} / \mathrm{S}$ at an elevation of $\sim 1247 \mathrm{~m}$ is west of the left-stepping normal faults that offset the ridge (Figure 5). These faults separate east-dipping blocks of cemented sandstone/conglomerate from flat-lying beds of similar material. The outcrops vary between fine-grained well-sorted sandstone to poorly sorted 
conglomerate, typically in beds $\sim 10 \mathrm{~cm}$ thick. Ripple marks, trough cross-beds, and root casts are common in the finer-grained beds. Sparse petrified wood is locally preserved. In the conglomerate beds, clast sizes are up to $5 \mathrm{~cm}$. Clasts are mainly basalt with rare andesite and rhyolite [1]. The coarser-grained conglomerates are exposed to the north and east, and maximum grain size decreases toward the southwest. No outcrop of the silicacemented sandstone/conglomerate is present east of the outflow channel from feature Q5 (Figure 7). In outcrops of the conglomerate and sandstone north of the parking area (Figure 4), bedding along an incised valley dips to the north. Loosely cemented sand is present in slope wash at and below $1247 \mathrm{~m}$ northeast of the parking area.

Locally, coarse-grained sand and small pebbles are suspended in opaline silica, suggesting coeval deposition of silica sinter and lithic clasts. Uranium series disequilibrium age dating at Argonne National Labs yielded a date of $<16,000 \mathrm{ybp}$ [2]. This poorly constrained date influenced interpretations of time of deposition of the sandstone/conglomerate and sinter mounds [2,4] (see Section 4).

\subsubsection{Current Hydrothermal Activity}

Active springs are present in two settings: (1) high-temperature springs at lower elevation, and (2) warm springs located within sinter features.

High-temperature springs at lower elevation occur in a $50 \mathrm{~m} \times 50 \mathrm{~m}$ roughly circular area at an elevation of $1230 \mathrm{~m}$ and south of the sinter mounds and depressions (Figure 4). Mud pots, the highest temperature springs, steam vents, and hot ground (Figure 10) are present in this area. The morphology of these thermal features is diverse and changes frequently. Within this area, (1) a mud pot (MP in Figure 10) erupted mud sometime between March and May, 2014; (2) geysering from the persistently highest temperature spring is reported by St. John and Cummings [50], Cross [51], and Kipple [52,53]; and (3) steam vents from small diameter orifices to the north and at slightly higher elevation form the highest temperature springs.

There is no evidence of current or past silica sinter deposition in this area. Water discharged from the high-temperature springs travels south toward dug-out ponds for watering cattle outside the ACEC fence. Carbonate is deposited in outflow channels where effluent temperatures are approximately $73^{\circ} \mathrm{C}$. Oestreicher [46] examined the microbiota within the temperature gradient found in these outflow channels.

The mud pots are typically 1-2-m-diameter depressions with a floor of wet bubbling mud. They are located near the southern edge of the high-temperature area and are flanked to the south by a 1.0- to 1.5-m-high berm of very poorly sorted sediment (Figure 11). Between March and May, 2014, a mud pot exploded and resurfaced the surrounding area ( $3 \mathrm{~m}$ radius) with sediments that were $70 \%$ moderately sorted silt and clay (see the grain size chart in Figure 11). The coarse portion was primarily basalt clasts but contained no silica sinter fragments.

The area of high-temperature springs, steam vents, and mud pots is bounded by ground that is warm to the touch on the north and west $(10 \mathrm{~cm}$ probe recorded a temperature between 67 and $95^{\circ} \mathrm{C}$ ), by a 1.5-m-high berm on the southwest (Figure 11), and a distinct change in sediment type on the east (Figure 10, right side of image). Together, the hot ground, berm, and sediment change encircle the high-temperature area and mark its outer extent. 


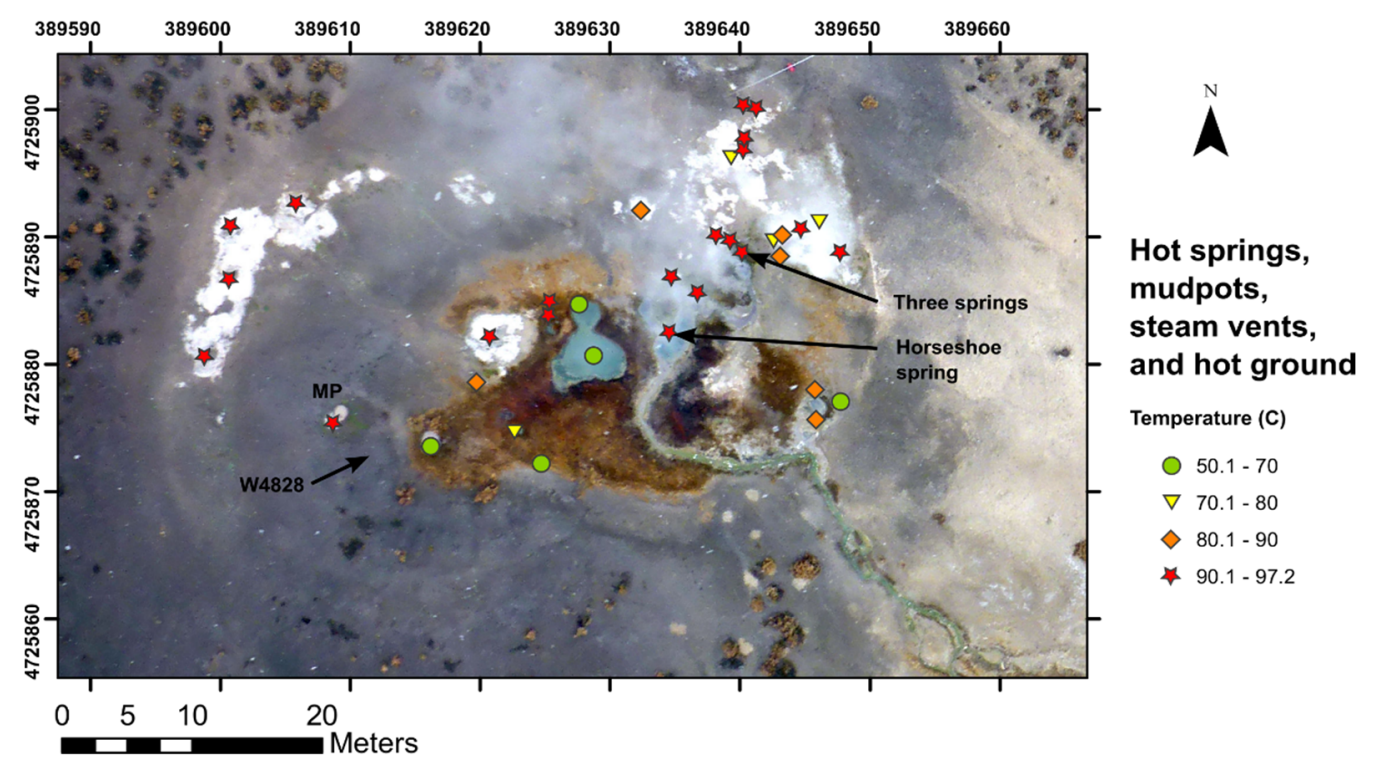

Figure 10. Most active springs, mud pots, and hot ground are concentrated in a $50 \times 50 \mathrm{~m}$ area at Mickey Springs. No sinter is present in this area, which is located $5 \mathrm{~m}$ below most sinter features. Location of the TL sample W4828 are indicated, and the mud pot (MP), which erupted between March and May 2014, resurfacing the area within a 3 m radius.

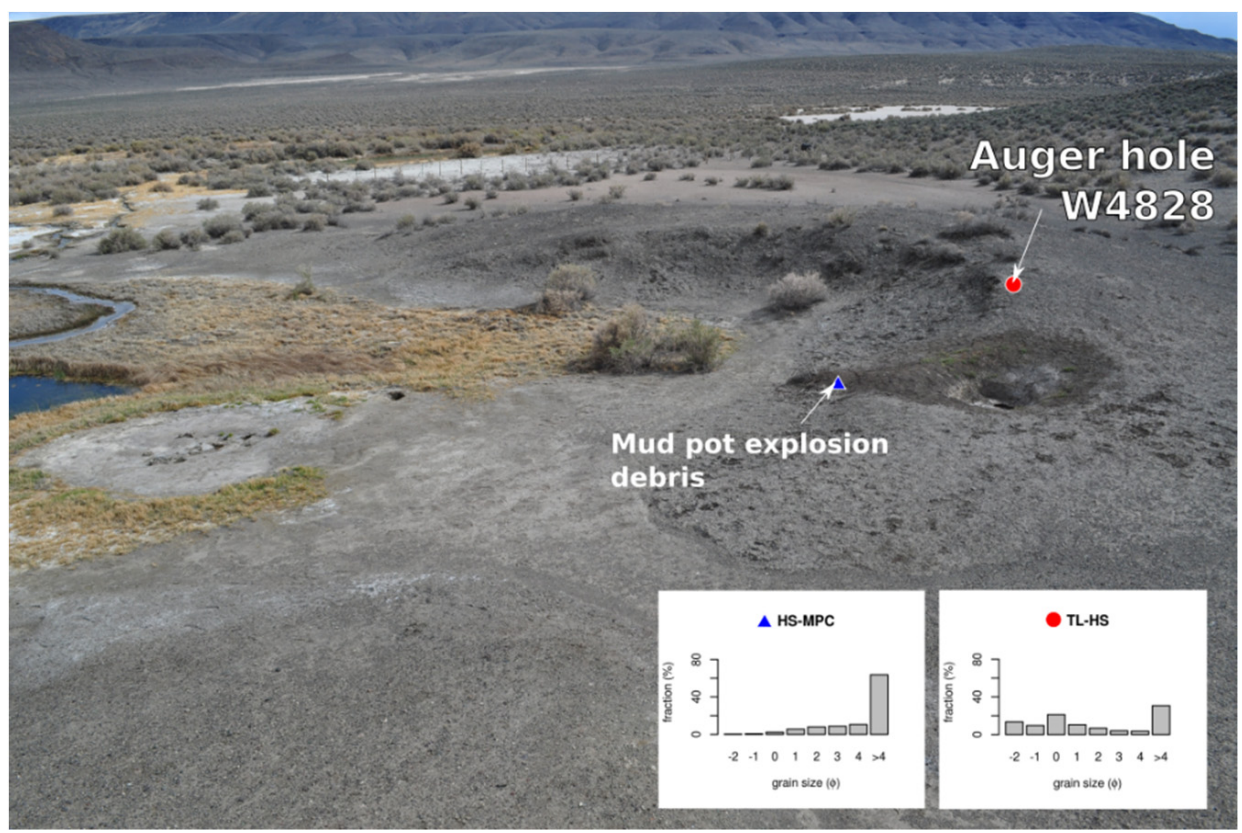

Figure 11. TL sample W4828 was collected from an auger hole in the berm southwest of the hightemperature area. The grain size chart for sample TL-HS (red dot) collected at the TL sample depth. The grain size chart HS-MPC (blue triangle) is for debris ejected from the mud pot between and March and May 2014. Note the elevated berm surrounding the SW portion of the high-temperature area, up to $1.5 \mathrm{~m}$ in height.

Warm springs located within sinter features are within the central depressions of feature D1 and a few sinter mounds (e.g., Q9). Spring temperatures in the central depression of D1 are included in Figure 8. Only one spring (Q5) supports a pool and has surface outflow.

Feature Q9 (Figure 12) is rimmed by up to $1 \mathrm{~m}$ (measured vertically) of inward dipping pool-edge sinter, with an apron diameter of $25 \mathrm{~m}$ and central depression diameter of $5 \mathrm{~m}$. The pool-edge sinter was sampled for uranium series disequilibrium dating [2] but was 
found unsuitable for dating. The relief between the apron rim and the depression is $1 \mathrm{~m}$. A muddy spring is present on the north edge of the floor of the depression. The water surface is continually rippling, presumably from gas discharge, which circulates microbial mats around the pool. Probing this pool with a metal rod revealed that the pool extends north under the sinter apron for at least the length of the rod $(1.5 \mathrm{~m})$.
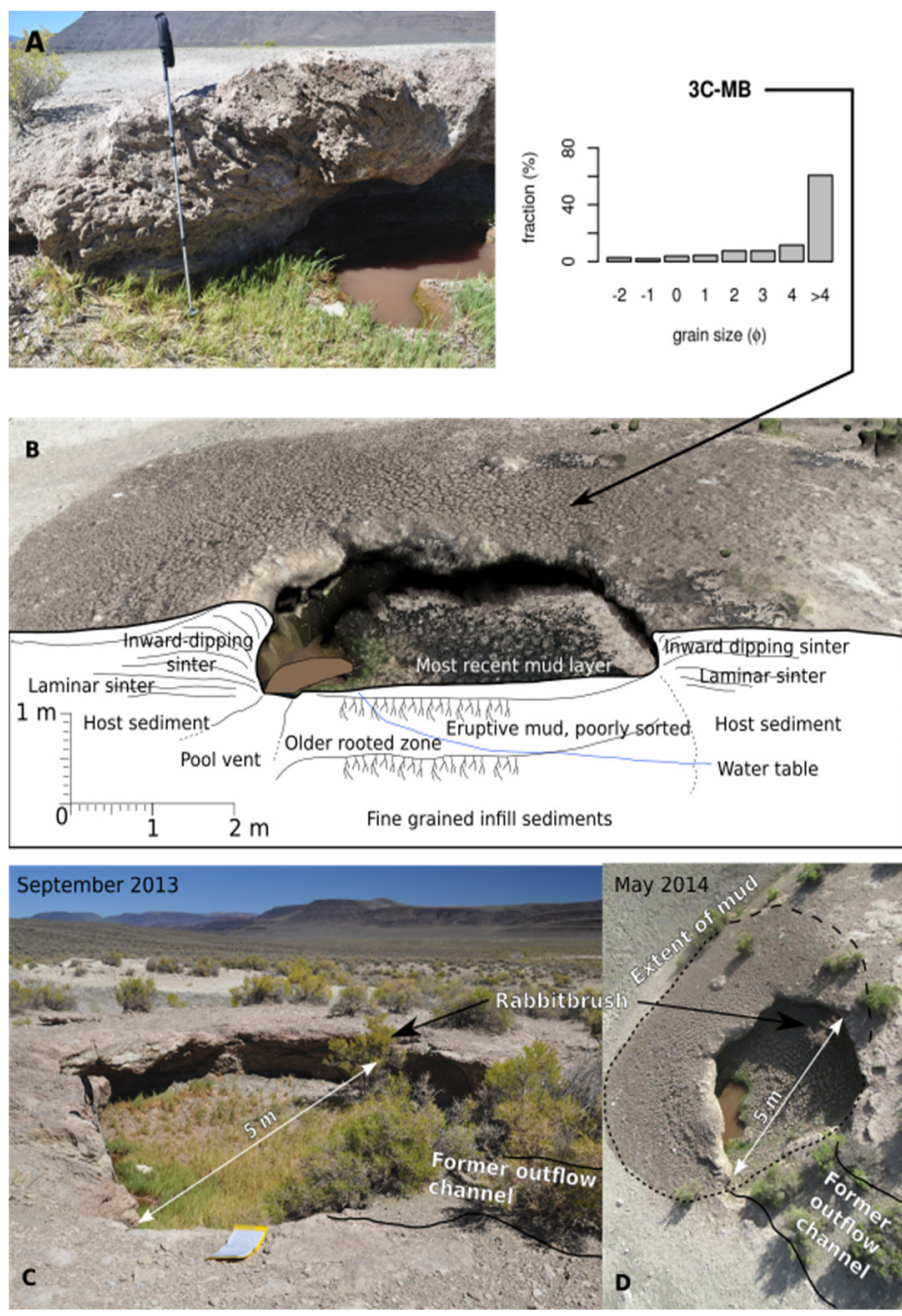

Figure 12. Feature Q9, resurfaced by mud explosion between March and May, 2014. (A): Inward dipping pool-edge sinter with wavy texture. (B): Cross-section of feature Q9. The central depression has been filled at least in part by explosive mud eruptions, killing vegetation and depositing up to $13 \mathrm{~cm}$ of new sediment in a single event. The grain size of the erupted sediment (3C-MB) is $70 \%$ fine-grained silt and clay, with few larger grains up to small pebbles. (C): Feature Q9 in September 2013, with grass present in the bottom of the depression and live rabbit brush. (D): Feature Q9 in May, 2014. The extent of the mud crust is indicated, thickest crust was $13 \mathrm{~cm}$, thinning toward outer edges. Stratigraphic column (right of image) from the auger hole in the center of the depression.

Feature Q9 was resurfaced by a mud eruption that occurred between March and May, 2014, emanating from the spring in the depression. The eruption deposited moderately sorted silt and clay over an area of $\sim 50 \mathrm{~m}^{2}$ to a maximum thickness of $13 \mathrm{~cm}$. The coarsegrained portion of this sediment (3C-MB, collected, as the arrow indicates in Figure 12, at the maximum thickness of the sediment) is $80 \%$ subangular to rounded lithic fragments, and $20 \%$ angular to subangular sinter. Cummings and St. John [2] report similar resurfacing at this site.

An auger hole in the depression (stratigraphic column right side of Figure 12) reached the rooted zone from the grass previously growing in the depression at a depth of $13 \mathrm{~cm}$. 
Below this rooted zone, sediment was primarily silty sand and sorting increased with depth down to $60 \mathrm{~cm}$. From 60 to $78 \mathrm{~cm}$ was another rooted zone, with poorer sorting and a higher percentage of coarse sand. Below this rooted zone, grain size decreased to $85 \%$ well-sorted silt and clay, green in color, and similar to the deeper sediment in D1. The water table was at $72 \mathrm{~cm}$. At a depth of $105 \mathrm{~cm}$, the auger broke through several gravel-sized sinter clasts. The total depth reached was $127 \mathrm{~cm}$, where saturation prevented the recovery of material.

\subsection{Thermoluminescence Dating}

The sampling strategy for thermoluminescence (TL) dating was to constrain the age of sinter deposition while respecting ACEC restrictions and, due to dangerously high ground temperatures, samples were limited to the shallow $(<1 \mathrm{~m})$ subsurface. Six sample sites were selected for TL dating and the results are summarized in Table 2, Figure 13, and Appendix A.

Table 2. Thermoluminescence dates from Mickey Springs, ordered on the left by Sample ID \#. Sample descriptions and limitation are included in Appendix A: TL Dating. Samples processed by David M. Price, Thermoluminescence Laboratory, University of Wollongong, Australia.

\begin{tabular}{cccccc}
\hline Sample ID & Associated Feature & $\begin{array}{c}\text { Temperature at } \\
\text { Sample Depth (C) }\end{array}$ & Sample Depth (cm) & TL Age (kya) & $\begin{array}{c}\text { Uncertainty } \\
( \pm \text { kya) }\end{array}$ \\
\hline W4823 & Q4 & 29 & 220 & 30.7 & 7.9 \\
W4828 & High-temp springs & 84 & 40 & 9.2 & 1 \\
W4829 & Q12 & 59 & 27 & 18.1 & 2.1 \\
W4830 & D1 apron & 33 & 47 & 17.5 & 3 \\
W4831 & Q3 & 36 & 53 & 0.8 & 0.4 \\
W4832 & D1 depression & 28 & 24 & 12.8 & 4.4 \\
\hline
\end{tabular}

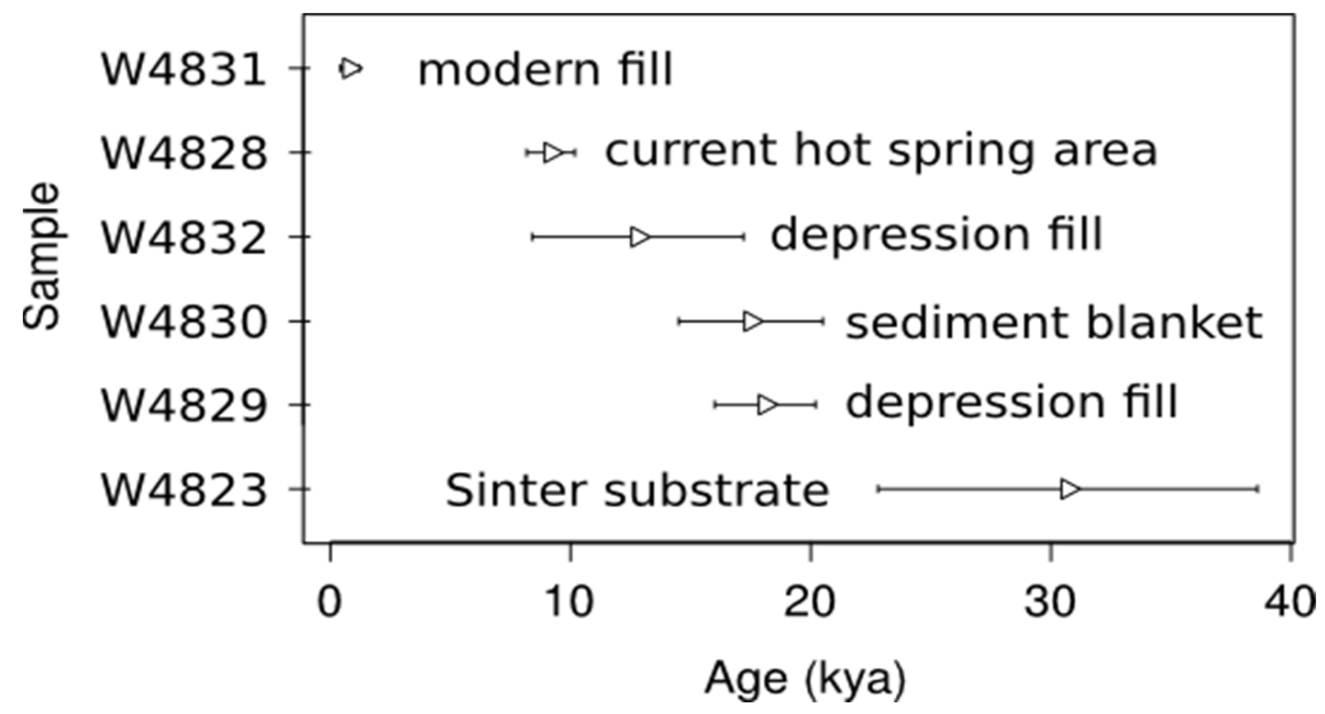

Figure 13. Barplot of TL ages, showing the age (triangle) and uncertainty (lines) of each sample. Material beneath the laminar sinter of Q4 is the oldest dated sample at $30 \mathrm{kya}$. Well-sorted finegrained sediment from depressions and blanketing sinter aprons range in age from 18-12 kya. The age of the sediment from near the current high-temperature springs is $\sim 9$ kya. The youngest TL date is from poorly sorted sand in feature Q3.

Potential underestimation of the true time of deposition by the TL process as used here may emerge from the heating of sediments by the hydrothermal water, cosmic ray contamination, or moisture content of the sample at time of processing. Appendix A contains information on the sample characteristics, analytical procedures, and results for 
these TL analyses. Sufficient heating can excite electrons, allowing them to escape from the crystal lattice, effectively reducing the TL age. Since all plateau and analysis temperatures were at or above $275^{\circ} \mathrm{C}$, it is assumed here that near-boiling spring water did not provide sufficient heating to bleach the samples. Despite the shallow sample depth used in this study, it is assumed that samples were sufficiently deep such that cosmic ray contamination did not significantly bleach the samples. Finally, the presence of moisture in sediment acts as radiation shielding, slowing the accumulation of electrons in the traps. The moisture content of the sample during the dating process is assumed to be constant through time; if the moisture content was higher in the past, then the actual age of sediments would be older than those determined by the TL process. Therefore, the ages reported here are considered the minimum ages.

At Q4 (Figure 6; sample W4823), a sinter mound, a sample was collected from unconsolidated sediment underlying laminated sinter. Sinter from two sources is present in the the Q4 sinter mound. The oldest, the laminated sinter, is part of the apron from a neighboring broad depression. The younger, the pool-edge sinter and thick-bedded sinter, was deposited when the Q4 mound vent was active. Sample W4823 was collected by augering horizontally into the wall of the central depression immediately below the laminated sinter (Figure 6) and from a horizontal auger distance of $30 \mathrm{~cm}$. The soil temperature was $29^{\circ} \mathrm{C}$ and the laboratory-measured moisture content was $22.2 \%$. The grain size of these sediments is presented in Figure 6. TL age is $30.7 \pm 7.9$ kya. Low TL sensitivity led to a temperature plateau comparison between 275 and $350{ }^{\circ} \mathrm{C}$, resulting in scattered TL data and an unusually large age uncertainty.

Sample W4828 was collected from the berm that circles the southwest portion of the high-temperature area (Figure 11) and near the rim of the mud pot that erupted between March and May, 2014. The sample was $40 \mathrm{~cm}$ below the surface. The soil temperature was $84^{\circ} \mathrm{C}$ and the moisture content was reported as $10.1 \%$. The sample included a large rock approximately half the volume of the total sample. This can distort the results of the TL process, but the grain size analysis and local observations show poor sorting of the sediments and therefore the sample was not considered anomalous for TL age determination. The age of this sample was $9.2 \pm 1.0$ kya.

Three samples were collected from the floors of the central depressions rimmed by sinter. Samples collected from two sites, Q12 (Figure 14) and D1 (Figure 8), were fine-grained sand, silt, and clay. At Q3 (Figure 15), the sample was very poorly sorted, sinter-bearing sand to gravel. These samples constrain the age of sediments that infill the vents.

Sample W4829 was collected at sinter mound Q12 (Figure 14) from an auger hole $27 \mathrm{~cm}$ below the surface of the central depression. The soil temperature was $59{ }^{\circ} \mathrm{C}$ and the laboratory-measured moisture content was 34.3\%. Sediments from 0-56 cm were poorly sorted, loose, sandy silt, with sparse clasts of sinter up to $4 \mathrm{~cm}$, but the sample sent for TL analysis was primarily sand and silt. TL output plateaued between 300 and $500{ }^{\circ} \mathrm{C}$, with a resulting age of $18.1 \pm 2.1 \mathrm{kya}$.

Sample W4831 was collected at a depth of $53 \mathrm{~cm}$ from the central depression of the sinter mound Q3 (Figure 15). A sinter apron surrounds this feature and pool-edge sinter is visible immediately surrounding an area of loose, poorly sorted silty sand with pebbles, flush with the sinter elevation. In the portion of the TL dating process that involved cleaning the grains with hydrofluoric acid (after treatment with $\mathrm{HCl}$ ), the sample reacted violently to the acid, indicating a high feldspar content. The coarse portion of the sediment contained $\sim 75 \%$ angular clasts of sinter up to $6 \mathrm{~cm}$ brought up in the auger and $\sim 25 \%$ coarse basalt sand up to $2 \mathrm{~mm}$. The soil temperature was $36{ }^{\circ} \mathrm{C}$ at $50 \mathrm{~cm}$ below the surface. The moisture content was reported as $4.1 \%$. The TL age was $0.8 \pm 0.4$ kya. 


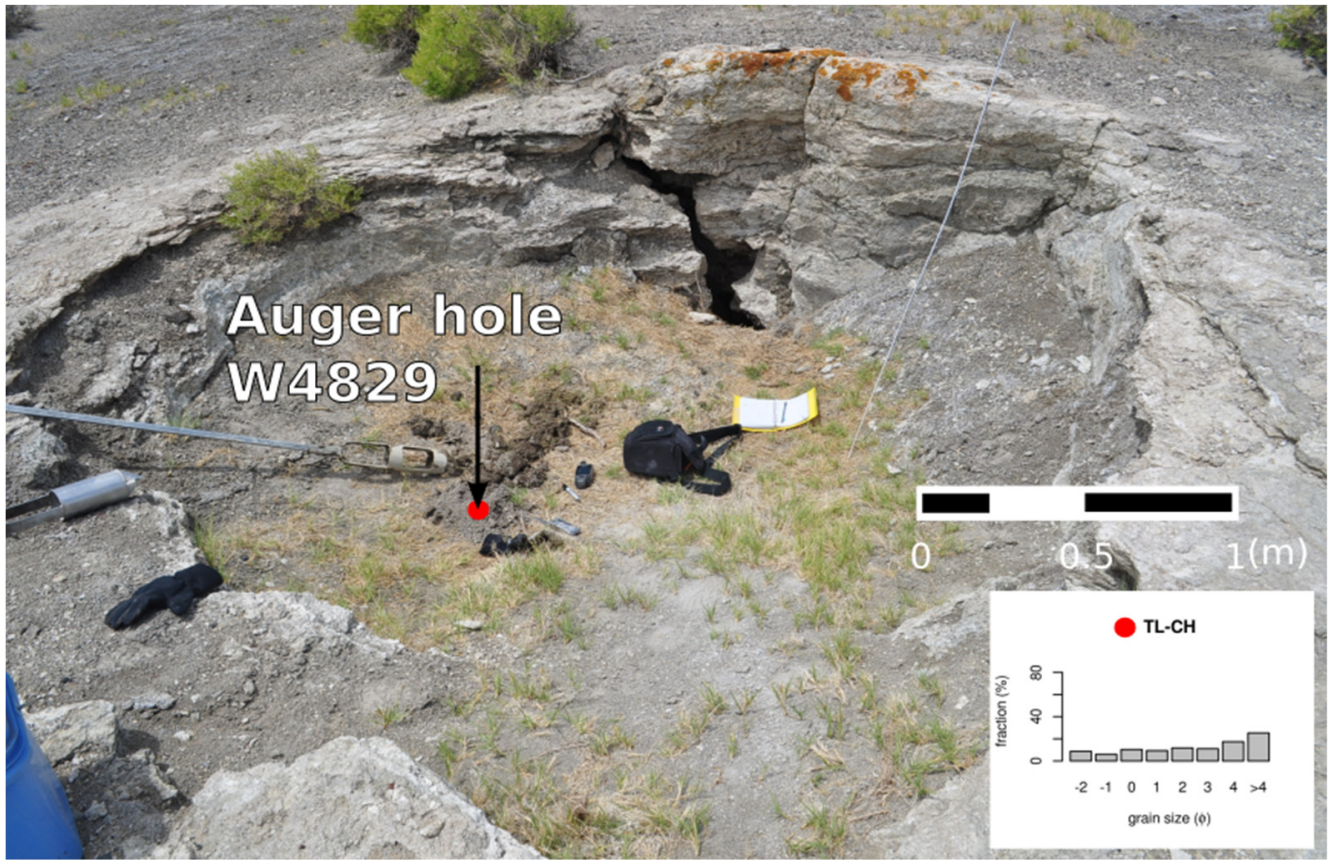

Figure 14. Image looking north at feature Q12, location of TL sample W4829. The fracture in the sinter is oriented N/NE and continuation is indicated by the linear orientation of bushes in the image. The grain size chart is shown for sample TL-CH, which was collected immediately above the TL sample depth of $27 \mathrm{~cm}$.

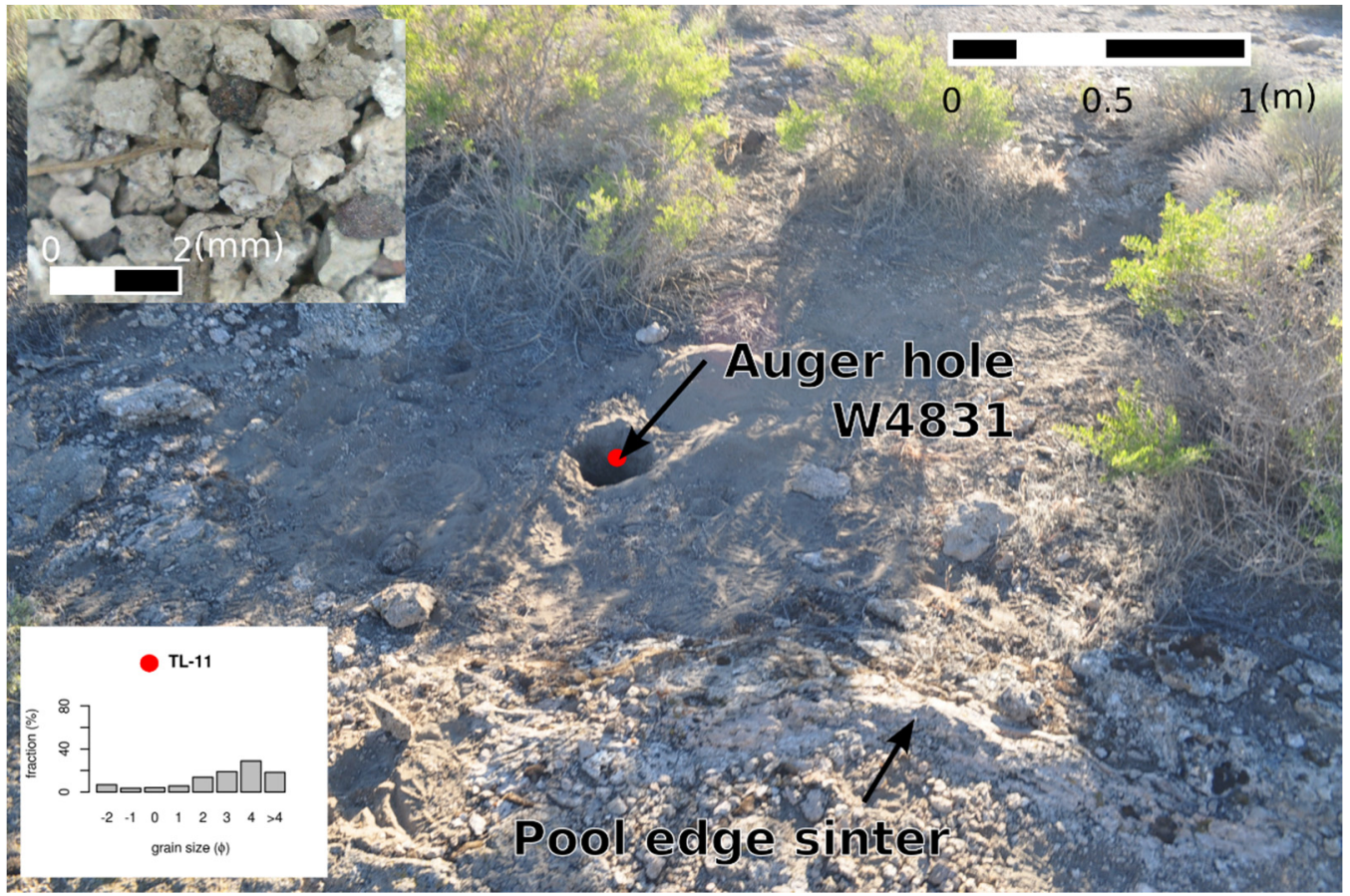

Figure 15. Location of TL sample W4831 in Q3. The sinter apron is relatively flat, with a central area of loose sediment level with the pool-edge sinter surrounding it. Sediment from the auger hole immediately above the TL sample depth (corresponding red dot) was 30\% fine sand, poorly sorted with gravel-size pieces of angular sinter and pebbles of sub-rounded basalt (inset top left).

Sample W4832 was collected in the broad depression of feature D1 (Figure 8) from $24 \mathrm{~cm}$ below the surface near the south edge of the central depression. This auger hole was adjacent to the hole for the sediment core shown in Figure 9d. The sample depth 
was $27-37 \mathrm{~cm}$, and was selected initially for practicality, as soil saturation made acquiring a deeper intact sample problematic with the tools used. However, this depth is at the transition from the surface sediment containing root fragments and the lower well-sorted silt and clay. The laboratory-measured moisture content was reported as $47.0 \%$. TL sensitivity was again low, leading to an above-average TL age uncertainty. The age of this sample was $12.8 \pm 4.4 \mathrm{kya}$.

Sample W4830 was collected from fine-grained sediments blanketing the sinter apron of the broad depression D1, $47 \mathrm{~cm}$ below the surface (Figure 16). The sediment at the TL sample depth was well-sorted, subrounded to rounded, sandy silt with $65 \%$ fine silt and clay. The soil temperature was $33^{\circ} \mathrm{C}$. The moisture content was reported as $32.2 \%$. The TL age of this sample was $17.9 \pm 3.0$ kya. TL sensitivity was similar to sample W4829, and the TL ages overlap within one standard deviation (Figure 13).

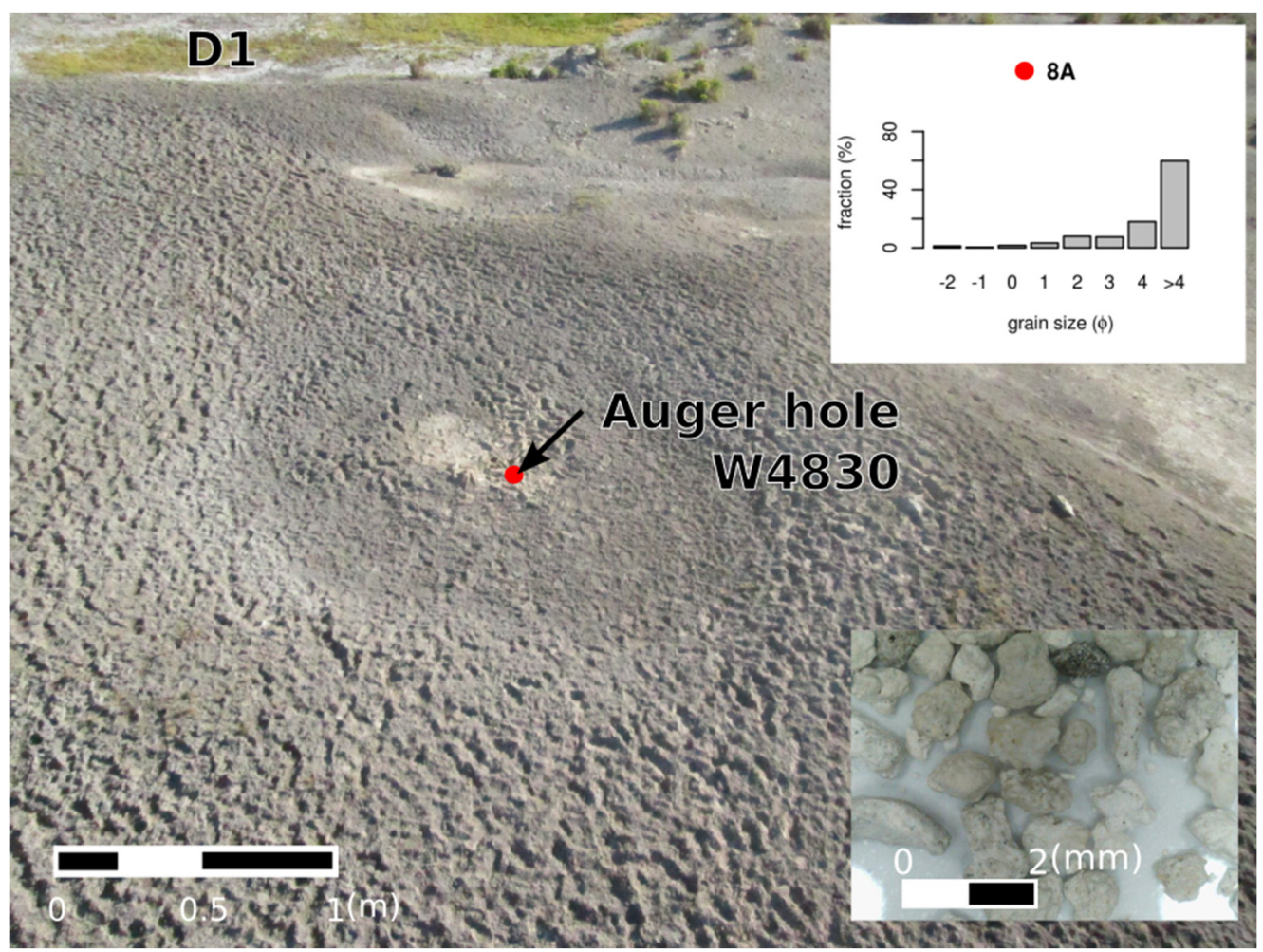

Figure 16. Location of TL sample W4830. The photo is looking north toward feature D1, on fine-grain sediment blanketing the sinter aprons surrounding the depressions. Photo taken in June, 2014 under dry conditions. Sediment in the auger hole is uniform, primarily $(65 \%)$ silt and clay with clasts of subangular to rounded sinter up to $6 \mathrm{~mm}$. The auger hole met refusal at $100 \mathrm{~cm}$. The grain size chart $8 \mathrm{~A}$ for sediment collected immediately above the TL sample depth of $47 \mathrm{~cm}$.

\subsection{Ground Penetrating Radar}

The preliminary GPR study reported by Mowbray and Cummings [4] used $250 \mathrm{MHz}$ shielded antennas spaced $0.5 \mathrm{~m}$ apart operating at 165 Volts with a horizontal resolution of $20 \mathrm{~cm}$ and a $2 \mathrm{~m}$ penetration depth. The track passed through the four broad depressions (Figure 5D1-D4) and extended onto the silica-cemented sandstone/conglomerate unit outcrops to the southwest. At the depth attained with the $250 \mathrm{MHz}$ antennas, the sandstone/conglomerate unit continued and is interpreted to underlie thin sinter deposits.

In May, 2014, three transects were surveyed with 1000 volt antennas (Figure 5). With these antennas, the top meter of the surface is noisy from the strength of the GPR signal extending in all directions, and only resolves subsurface features greater than 1-2 $\mathrm{m}$ below the surface, below the maximum thickness of most sinter aprons. Two tracks ( 1 and 3 ) were made from west to east, and one track (2) was made from north to south. Both 50 and 
$100 \mathrm{MHz}$ antennas were deployed on track 1, while only $50 \mathrm{MHz}$ antennas were deployed on track 2 and 3 . The $50 \mathrm{MHz}$ antennas were able to penetrate to a depth of approximately $17 \mathrm{~m}$, while the $100 \mathrm{MHz}$ antennas penetrated to a depth of approximately $10 \mathrm{~m}$. All GPR tracks are shown with and without topographic correction in Figure S1: GPR raw data and topographically corrected data.

Track 1 (Figure 17) was surveyed using the $50 \mathrm{MHz}$ (Figure S1: GPR raw data and topographically corrected data for Track 1, $50 \mathrm{MHz}$ ) and the $100 \mathrm{MHz}$ (Figure S2: GPR raw data and topographically corrected data for Track 1, $100 \mathrm{MHz}$ ) antennas, over a distance of $222 \mathrm{~m}$. The track started at the high point of the silicified sandstone, passed just north of the central depression of feature Q4, crossed the center of feature D1, and terminated before the east fence of the ACEC. A 5-m gap in the $50 \mathrm{MHz}$ track on the crest of Q4 was caused by temporary disconnection of the antennas from the recording computer.

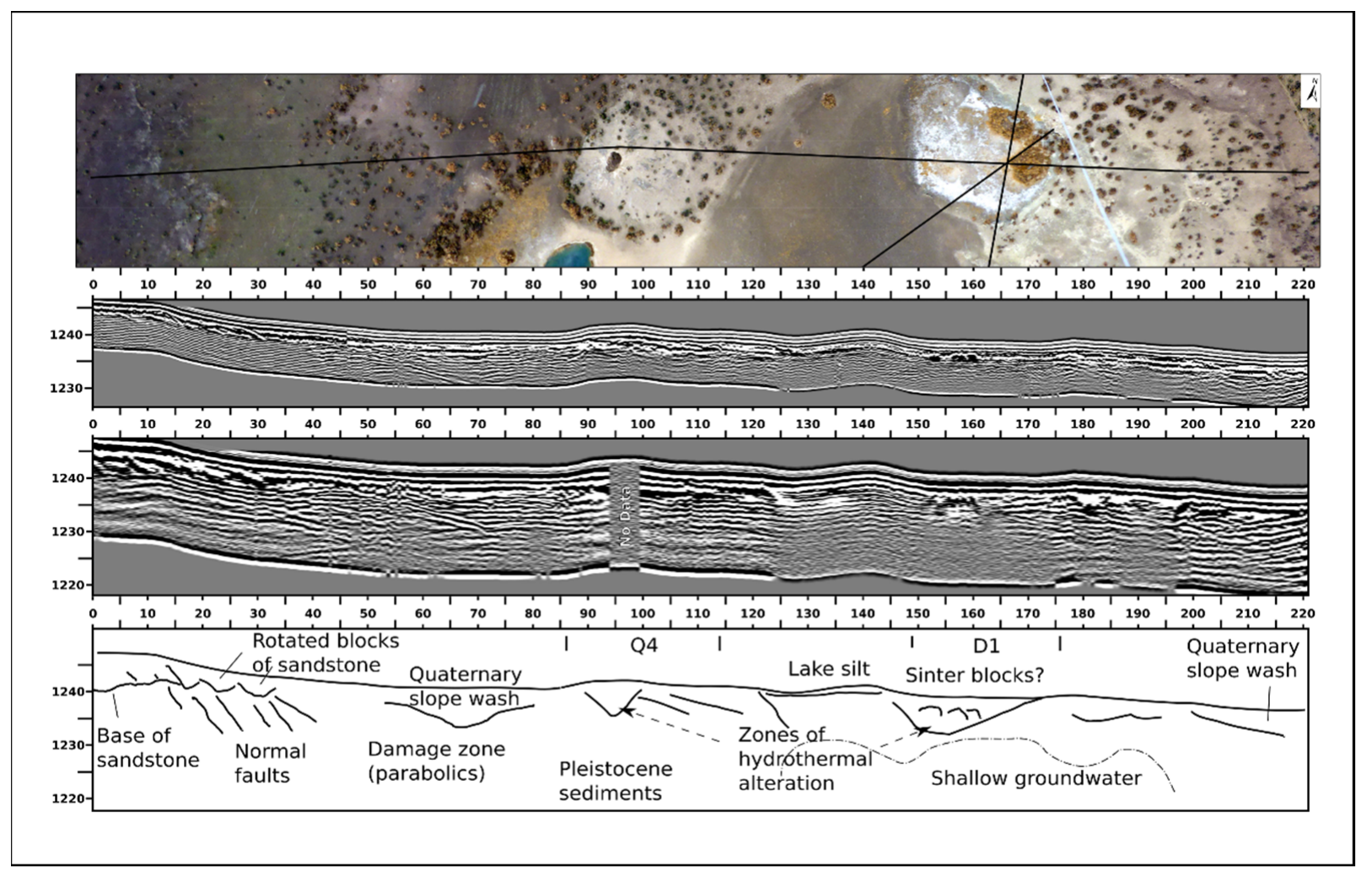

Figure 17. GPR transect 1 from west to east, descending from the silicified sandstone outcrop, across feature Q4 and D1, and terminating at the east fence of the ACEC. (Figure S1: GPR raw data and topographically corrected data for Track 1, 50 MHz. Figure S2: GPR raw data and topographically corrected data for Track 1, $100 \mathrm{MHz}$ ).

Track 2 (Figure 18) was surveyed using $50 \mathrm{MHz}$ (Figure S3: GPR raw data and topographically corrected data for Track $2,50 \mathrm{MHz}$ ) antennae over a distance of $265 \mathrm{~m}$. This track traversed feature D1, crossed the west flank of the sinter apron of Q9, passed west of Q12, crossed the center of the high-temperature spring area, and terminated at the south fence of the ACEC.

Track 3 (Figure 19) was surveyed using the $50 \mathrm{MHz}$ (Figure S4: GPR raw data and topographically corrected data for Track 3, $50 \mathrm{MHz}$ ) antennae over a distance of $180 \mathrm{~m}$. The track began west of the sandstone ridge over sparsely vegetated soil, where no outcrop was present, crossed the high-temperature area just north of the mud pots and high-temperature spring outflows, and over a small rise east of the high-temperature springs, terminating at the east fence of the ACEC. 


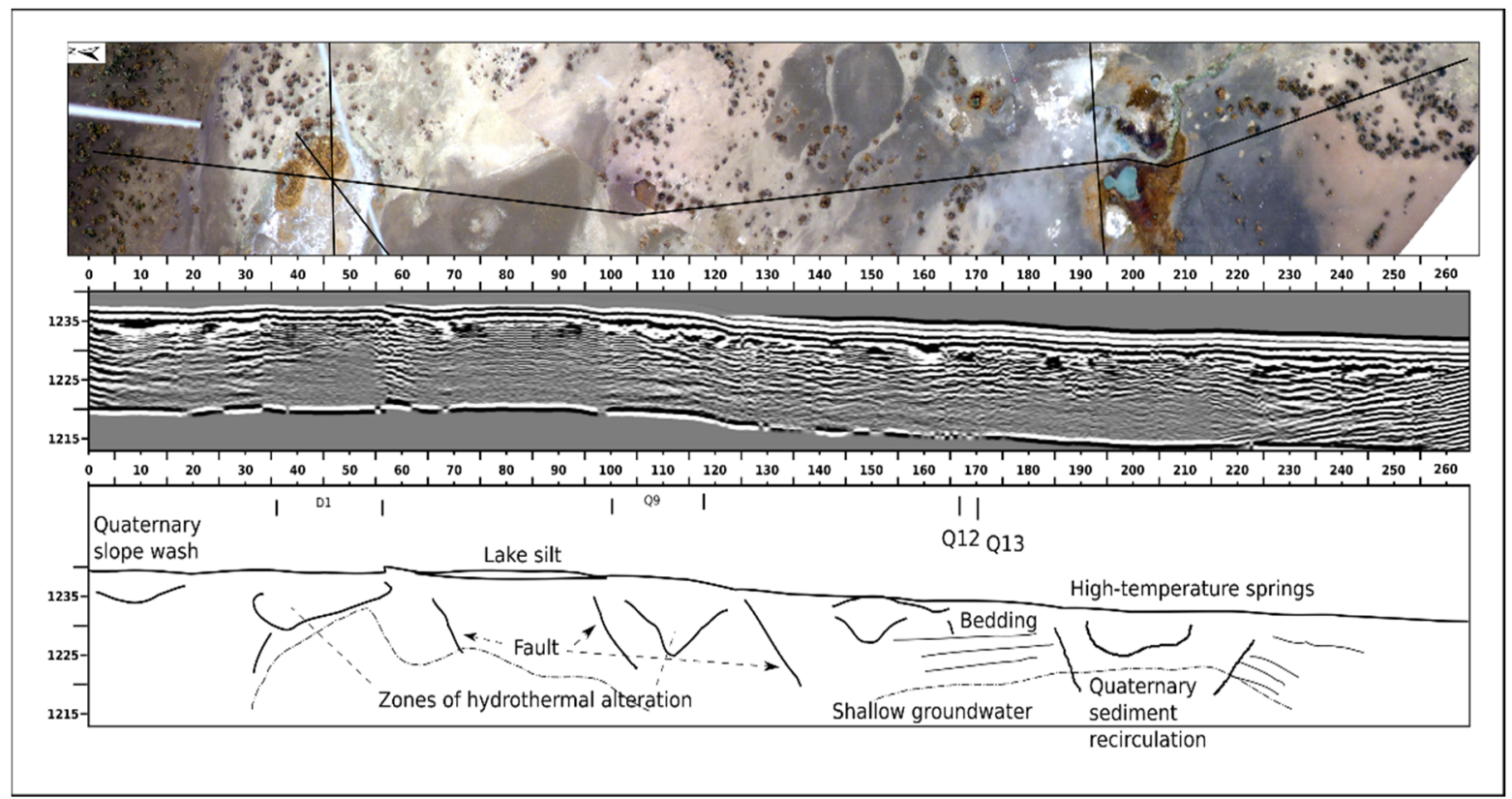

Figure 18. GPR transect 2 from north to south crossing sinter feature D1, the west flank of the sinter apron of Q9, and the high-temperature spring area, terminating at the south fence of the ACEC. Three normal faults are interpreted from the GPR data, striking northeast. These faults control the elevation of the topographic bench at $1235 \mathrm{~m}$ and may provide permeable pathways for the spring water (Figure S3: GPR raw data and topographically corrected data for Track 2, $50 \mathrm{MHz}$ ).

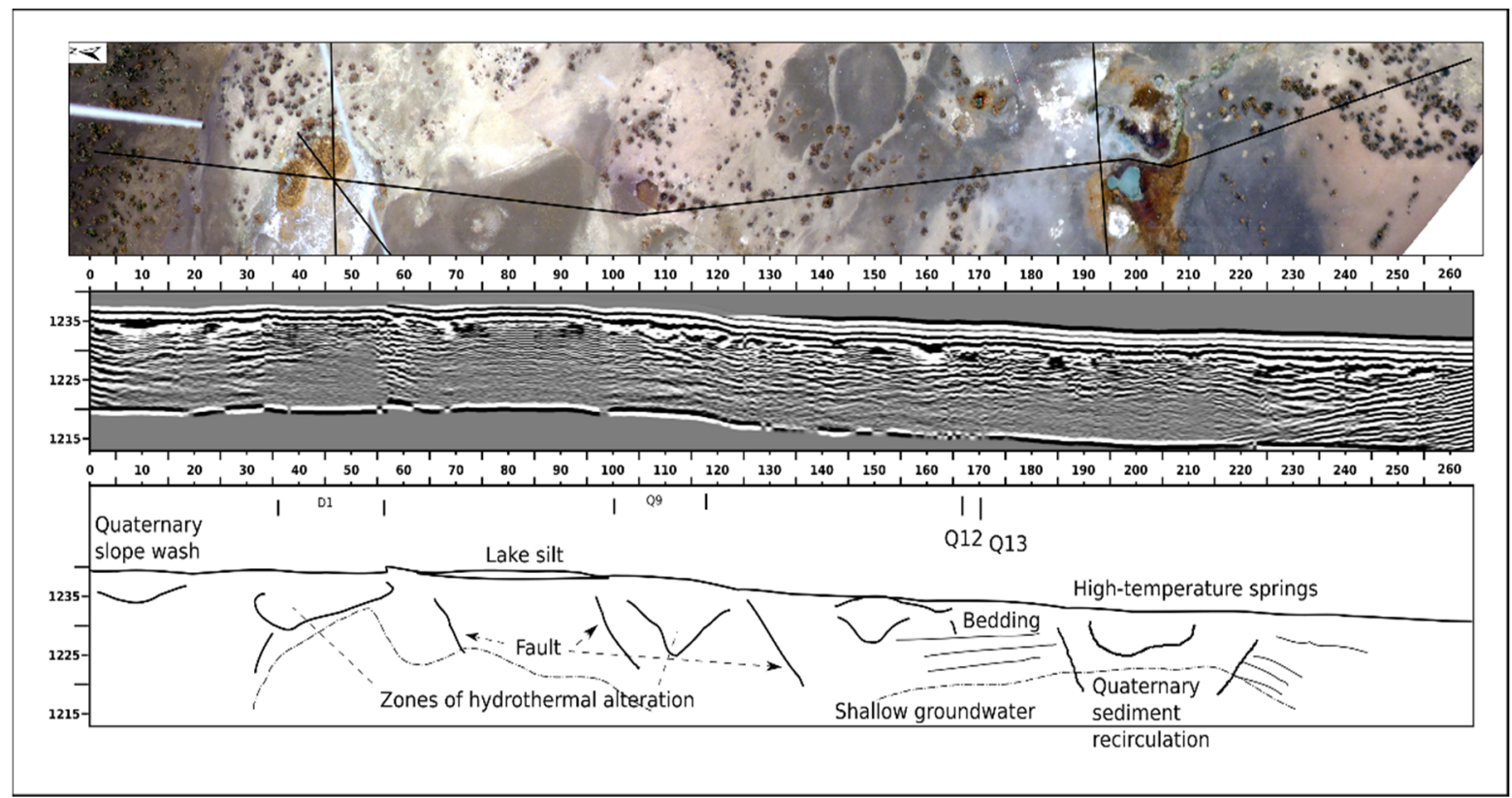

Figure 19. GPR transect 3 from west to east across the high-temperature area of Mickey Springs. An unconformity underlies the unvegetated area of the high-temperature springs. Thick peaks and undulating bedding may indicate the location of fluid pathways for surface springs (Figure S4: GPR raw data and topographically corrected data for Track 3, 50 MHz).

Broad parabolic reflections are visible in all three GPR tracks before the addition of topography (Figures S1-S4). Once topography was added, the parabolic reflectors are distorted. The width of the parabola indicates the presence of a zone rather than a point feature. These broad parabolas can be produced by zones of material with a different density or electrical properties to that of the surrounding area. Possible causes for these 
could be the damage zone around a fault and/or a zone of hydrothermal alteration around a conduit for hydrothermal fluid.

Common features visible in the 50 and $100 \mathrm{MHz}$ images are (1) the dipping beds of the silicified sandstone, (2) deterioration of the signal due to thick silt at the ground surface, and (3) alteration of the signal due to shallow groundwater. All three GPR transects terminated near the fence line of the ACEC. Strong reflectors in the GPR tracks rise toward the termination point of each track and are interpreted as air-wave signals from the fence posts, and determined not to be indicative of the subsurface structure. Topography-corrected raw data for the transects are reproduced here (Figures 17-19) and the stratigraphic interpretations based on these data are illustrated below each transect.

The dominant texture in the GPR tracks is sub-horizontal to gently dipping lines, found primarily in the lower two-thirds of the imaged areas. This is interpreted to be a relatively uniform unit of underlying sediment, indicating that all sinter precipitated at Mickey Springs is near the surface and forms a relatively thin capping unit.

The silica-cemented sandstone/conglomerate unit was exposed at the surface on the western portion of track 1 (Figure 17). The GPR image shows some thick (compared to the thin sub-horizontal bedding of the underlying sediment) horizontal bedding accompanied by east-dipping lines. The thick horizontal bedding extends $5-10 \mathrm{~m}$ in depth and is thicker than the thin horizontal lines of the bottom two-thirds of the transect. Because these lines are coincident with the sandstone outcrop, they are interpreted to trace the subsurface extent of the sandstone and indicate the sandstone/conglomerate unit is only $\sim 10 \mathrm{~m}$ thick. Similar texture is not visible in the GPR data from the eastern portion of track 1 , nor in track 2 or 3.

The east-dipping lines in the sandstone/conglomerate unit in track 1 continue at depth in the thinner-bedded sediment as discontinuities in bedding. These discontinuities are interpreted as faults, and are in proximity to many parabolics, indicating a damage zone (Figures S1-S4). Three faults are also interpreted from track 2 (Figure 18) at discontinuities in bedding. These faults are coincident with the slope break between the topographic bench containing the sinter mounds and depressions at $1235 \mathrm{~m}$, dipping toward the current high-temperature springs to the southeast.

Areas below sinter aprons have non-uniform bedding planes and discontinuities, typically approximating the width of the apron or depression and narrowing downward. From the exposure in the depression of Q4, the planar-bedded sediments below the laminar sinter appear as primary deposition that remains unaltered by the thermal waters that deposited the sinter; however, the GPR data suggests a zone of alteration underlying each feature.

The area of the high-temperature springs in the E/W transect of track 3 (Figure 19) appears blocky and undulating down to $10 \mathrm{~m}$, while the N/S transect of track 2 does not have similar blocky features. Both transects indicate a discontinuity of bedding at 5-10 m beneath the high-temperature area. Some of the largest blocky light and dark zones in track 3 coincide with the main high-temperature springs, which flow from cracks primarily oriented N/S. The blocky features are therefore likely showing the shallow subsurface structure on which the fluid is rising. Several parabolics are also present just beneath the blocky area and may indicate the continuation of the conduit at depth (Figure S4: GPR raw data and topographically corrected data for Track 3, $50 \mathrm{MHz}$ ).

\section{Discussion}

Silica sinter deposition requires the discharge of hot water with colloidal silica suspended in the effluent. Deposition of the colloidal silica occurs as the solution cools to form pool-edge sinter and outflow channels across the surrounding apron. Encrustation of algae in the pool and outflow channels and vegetation growing on the apron are well documented (e.g., [17-19,46]). These conditions were met before the Alvord Valley was inundated by late Pleistocene pluvial Lake Alvord at Mickey Springs and during the Holocene at Borax 
Lake [3]. In this discussion, the stratigraphic, age, and structural relations are examined, and a timeline presented for the sinter deposits at Mickey Springs.

\subsection{Stratigraphic Relations}

GPR applied to geothermal systems with siliceous sinter deposits was introduced by Dougherty and Lynne [54] and Lynne and Dougherty [55]. The technique has been applied to siliceous sinters at Opal Mound, Utah, Steamboat Springs, Nevada, and Horohoro and Pukemoremore in the Taupo Volcanic Zone, New Zealand [56] and at Old Faithful Geyser in Yellowstone National Park [57] to examine the thickness of sinter deposits (to about $10 \mathrm{~m}$ ) and the distribution of fracture systems associated with hot springs and sinter deposits.

GPR surveys and SfM photogrammetry helped resolve two questions at Mickey Springs: (1) What is the stratigraphic relation between the sinter mounds/broad depressions and the sinter-bearing silica-cemented sandstone/conglomerate unit? (2) What are the characteristics of the subsurface environment beneath the sinter deposits?

East-dipping bedding in the sinter-bearing silicified sandstone/conglomerate unit has been interpreted either as foreset beds or tilted fault blocks. Cummings and St. John [2] interpreted the dipping beds in these outcrops as the foreset beds of a delta that prograded into pluvial Lake Alvord. The uranium series disequilibrium date of $<16,000 \mathrm{ybp}$ [2] available at that time was consistent with this interpretation of coeval sedimentation and sinter deposition. This interpretation suggested that subaerial sinter deposition in the mounds and depressions had occurred at Mickey Springs after the pluvial Lake Alvord dried.

This interpretation also guided the thinking in Mowbray and Cummings [4] as they presented a climate-driven model for the evolution of the Mickey Springs site. In this model, sinter deposition ceased during the Holocene as a lagged response to the warming climate and drying of pluvial Lake Alvord. When Pluvial Lake Alvord was present, it provided recharge to the deep heat source below the Steens Basalt. Although fault slip continued through the Holocene to maintain permeable pathways $[8,10]$, the meteoric water available to the system diminished with the drying of the lake. The preliminary GPR study [4] at the depth attained with the $250 \mathrm{MHz}$ antennas seemed to confirm that the foresets of the silicified delta continued and underlie the sinter deposits.

Reinterpretation of these outcrops based on SfM photogrammetry (Figure 5), additional field work, and $50 \mathrm{MHz}$ and $100 \mathrm{MHz}$ GPR transects (Figures 17-19) supported tilted blocks along left-stepping, down-to-the-east, north-striking normal faults to explain these east-dipping blocks of sinter-bearing silica-cemented sandstone and conglomerate. In Figure 5, left-stepping normal faults are shown separating the sinter-bearing silicacemented sandstone/conglomerate unit from the area of sinter mounds/broad depressions. This reinterpretation aligns better with sedimentological details in outcrops where the depositional architecture of bedding and relations between sandstone and conglomerate layers are more consistent with deposition on an alluvial fan rather than deposition on a delta front. The GPR data are consistent with this reinterpretation. However, the deeper resolution of the $50 \mathrm{MHz}$ antennas shows that the sandstone/conglomerate unit is not continuous at depth under the sinter mounds/broad depressions and spring area.

The GPR data and outcrops at sites, such as Q4, Q9, and D1, indicate that the sinter aprons around springs are thin. At Q4, the total sinter thickness exposed in the vent walls is $2 \mathrm{~m}$. This is similar to direct and indirect observations at other sinter mounds and sinter rims around broad depressions. There is no evidence from observation or in the GPR transects of stacking of sinter deposits at several levels beneath the features observed at the modern surface. The GPR data are consistent with areas of stratigraphic disruption (faults/fractures) and potentially hydrothermal alteration underlying hot spring vents.

\subsection{Timing of Sinter Deposition}

The ages of the silica sinter deposits at the three hot springs in the Alvord/Pueblo valleys are reported for Borax Lake $[3,47,58]$ and at Mickey Springs $[2,5,47]$. The age of the sinter deposits at Alvord Hot Springs has not been determined. 
At Borax Lake in the Pueblo Valley, a seismic refraction study [3,58] indicated that the 8.3-m-thick biomorphic mound overlies silt- and clay-rich sediment deposited in pluvial Lake Alvord. Pool-edge sinter rims the 4-hectare lake, which commands the crest of the shield-shaped mound. The mound is comprised of diatom frustules, silt-size opal-A silica particles, silica-encrusted and permineralized vascular plant fragments, sinter fragments, discontinuous carbon-rich plant layers, charcoal layers, and sparse hard sinter layers. A $1.2 \mathrm{~m}$ long, $0.64 \mathrm{~cm}$ diameter wooden dowel was used to probe the flanks of the mound below the sinter apron that surrounds the lake. Resistance was rarely encountered and locally, the dowel would sink under its own weight. An AMS radiocarbon date for a discontinuous charcoal layer below the sinter apron that extends northward from the lake shore is BC 3775 to 3655 calibrated calendar years ( $4930 \pm 60$ RCYBP, \pm 1 S.D.; elevation $=1242.93 \mathrm{~m}$ ). A calibrated calendar age of AD 1420 to 1455 (470 \pm 50 RCYBP; elevation $=1237.81 \mathrm{~m}$ ) was obtained from charred plant material immediately above hard silica sinter on the east flank of the mound. A normal fault displaced silica sinter and a charred layer with a calibrated calendar age of AD 685 to $800(1270 \pm 50$ RCYBP; elevation = $1236.73 \mathrm{~m})$ north of Borax Lake [3]. This fault is one of the active left-stepping normal faults that control hot springs north of Borax Lake and was included in an investigation of fluid flow and distribution of permeability in an active fault zone [11-14]. Based on the microcrystallinity of sinter at Borax Lake, Nicholson et al. [43] interpreted the age of sinter deposition to be 4 kya.

At Mickey Springs, the age of coeval deposition of silica sinter, sand, and conglomerate is poorly constrained. Cross bedding, root casts, fragments of petrified wood, and subangular pebbles and cobbles suggest these coarse-grained sediments accumulated on an alluvial fan. The extent of sinter-bearing silica-cemented sandstone and conglomerate (Figure 4) suggests the discharge of thermal water may have been relatively diffuse. At best, sinter deposition is constrained within the long time span between the high stands of pluvial Lake Alvord that produced the Serrano terraces ( 130 kya, [10]) and the 30 kya TL date for unconsolidated sand beneath sinter at Q4.

Deposition of sinter mounds and broad depressions started at approximately 30 kya and persisted until late Pleistocene pluvial Lake Alvord occupied the Alvord basin. This history was constructed using TL dating, GPR surveys, SfM photogrammetry, granulometry, and stratigraphic relations. Sinter deposition at the sinter mounds and broad depressions based on the crystallinity of the sinter (opal-CT) was estimated at 30 kya [43]. This is consistent with the TL date presented in this study for feature Q4 (Figure 6), where a sample collected beneath the laminated sinter deposit and underlying un-cemented sediment yielded an age of 30 kya but with relatively large error (Sample W4823, Table 2).

Sinter deposition had ceased at Mickey Springs prior to submersion in pluvial Lake Alvord. Two lines of evidence support this interpretation: (1) sinter sand, cobbles, and pool-edge sinter ensconced in silt and clay; and (2) the TL dates for the infilling sediments.

First, the sediment that infills the vents of the sinter mounds and broad depressions is dominated by silt and clay. The fine-grain size and sorting are consistent with lacustrine deposition. Sand to cobbles and blocks of pool-edge sinter are ensconced in the infilling fine-grained material. The buried sinter cobbles and blocks require the sinter to have been present before sedimentation.

Second, TL dates from the Q12 (sample W4829, Figure 14) vent and sediment covering the apron of the D1 broad depression correspond to the determined age of the early filling stage of pluvial Lake Alvord. The materials submitted for TL dating from the sinter mounds and broad depressions were opportunistically collected at the depth where sediment return in the hand auger was successful. Thus, the dates do not mark specific horizons within the filling sediment. However, the oldest date from this setting, 18.1 kya, from the Q12 site (sample W4829) is consistent with age determinations for the times when pluvial Lake Alvord occupied the Alvord basin [37]. Sediment covering the aprons of broad depressions and sinter mounds postdates sinter deposition. At the D1 broad depression, this material near the contact between silty sediment that overlies the silica sinter apron was dated at 
17.9 kya (W4830, Figure 16). Uncertainty of the age of this sample and that from the central depression of Q12 (W4829) overlap within the precision of the technique (Figure 13).

The younger age for infilling materials at the D1 site was for a sample collected near the contact between rooted sediment characteristic of the upper part of this auger hole and underlying clayey silt deposits (Figure 9). This age, $12.8 \mathrm{kya}$, suggests deposition during the late stages of pluvial Lake Alvord.

The berm located southwest of the high-temperature area is interpreted to be ejecta from the high-temperature mud pot/springs area and to have been constructed after the drying of pluvial Lake Alvord. An age date for sediment near the mud pots, 9.2 kya (W4831, Figure 11), was collected from a site with no known sinter deposits. Clasts of sinter were not present in the debris that blanketed part of this area from the mud pot explosion between March and May 2014. The GPR image suggests a discontinuity in bedding of sediments within the high-temperature area, and the berm delineates the boundary of this area.

The youngest TL age was determined for sandy sediment including basalt lithics $(\sim 25 \%)$ and angular silica sinter clasts $(75 \%)$ at the Q3 site (Figure 15$)$. The Q3 site is one of the northernmost sinter deposits and is at an elevation similar to the landscape that lies north and northwest of the sinter deposits. This age, $0.8 \mathrm{kya}$, may reflect inundation of this sinter deposit by sheet wash from a flash flood event originating on Mickey Butte.

TL dates and crystallinity of sinter (opal-CT) [47] suggest hydrothermal discharge has occurred at the Mickey Springs site for at least 30,000 years. However, sinter deposition that formed the sinter mounds and broad depressions commenced sometime after 30 kya and ended sometime around 18 kya before the filling of pluvial Lake Alvord. The grain size data and TL dates are consistent with sedimentation from late Pleistocene pluvial Lake Alvord infilling vents of hot springs that had previously produced sinter deposits. The TL age dates are consistent with the span of ages reported for late Pleistocene pluvial Lake Alvord and the grain sizes are consistent with those likely produced from the glacial flour released into the basin from melting glaciers on Steen Mountain.

The thin sinter deposits suggest that deposition of sinter at the sinter mounds and broad depressions was short lived. GPR data suggest there is no stacking of sinter deposits one upon the other, at least within the $17 \mathrm{~m}$ resolved by the $50 \mathrm{MHz}$ antenna surveys. The TL dates suggest that deposition occurred over a relatively short period of time bracketed by the 30 kya date at Q4 and the ages of lacustrine silt deposited in inactive vents by at least 18 kya.

\subsection{Structural Interpretation}

The field-based structure map by J.S. Oldow (fide [15]; Figure 3) placed Mickey Springs at interacting fault tips in a system of northeast-striking normal faults. The analysis of temperature data [15] suggest that the Mickey Springs site is located "in a fault tip-line region or in a releasing step within an obliquely slipping fault intersection area." SfM photogrammetry, additional field investigations, and GPR were used to refine the model presented in Figure 20. The changes to the map of J.S. Oldow (fide [15]) include the addition of (1) north-striking, left-stepping, down-to-the-east, normal faults and (2) a down-to-the south, northeast-striking normal fault. 


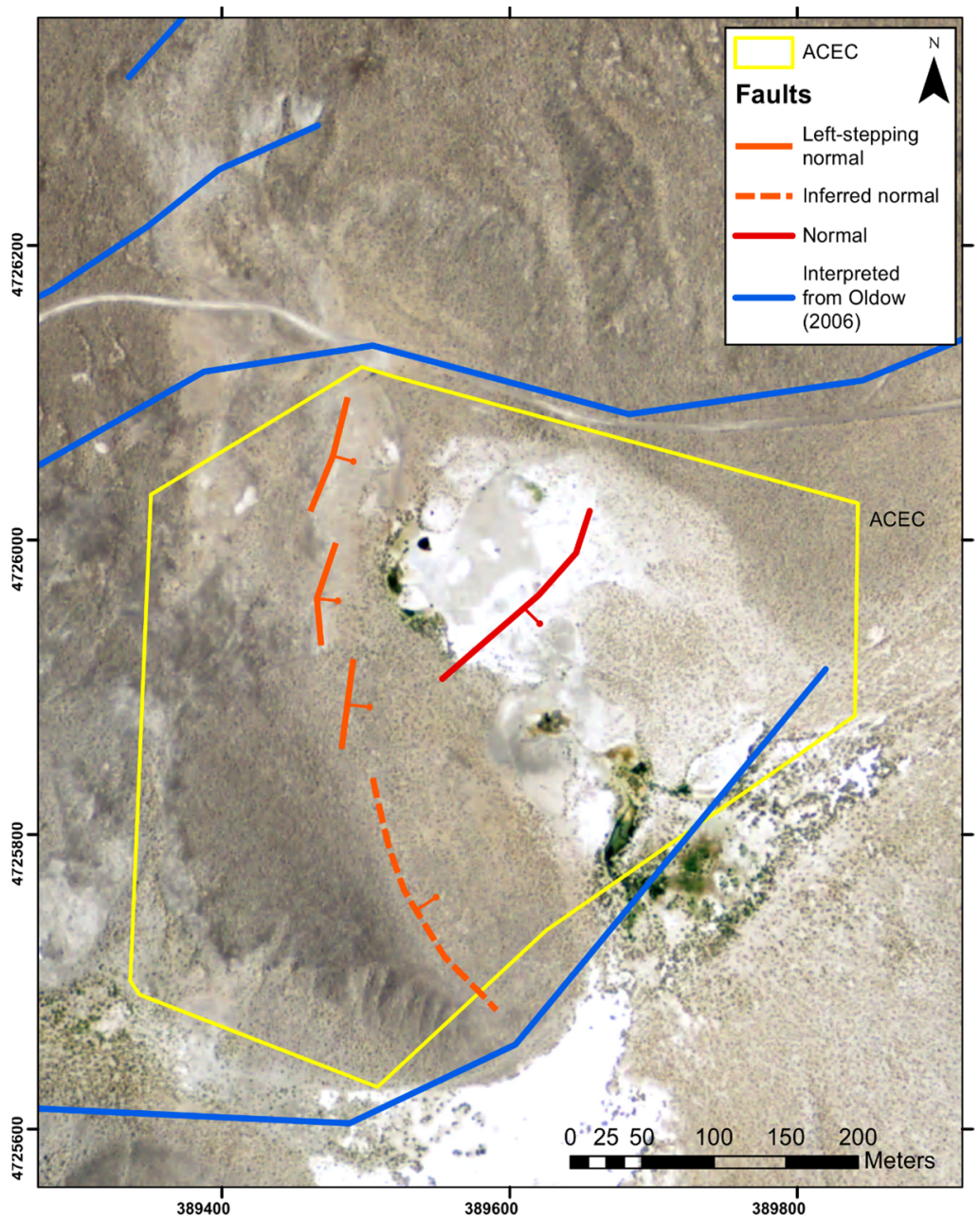

Figure 20. Structural map of the Mickey Springs area. Interacting fault tips proposed by Oldow (fide [15]) constrained the location of hydrothermal activity during cementation of sandstone and conglomerate unit (blue lines). All sinter at Mickey Springs is contained within this area. Development of a north-striking left-stepping fault before $30 \mathrm{kya}$ offset the sandstone and further constrained the fluid pathways in the subsurface (orange lines). All sinter mounds and depressions are east of this fault. Most sinter mounds and all depressions are on a topographic bench between 1235 and $1240 \mathrm{~m}$, which is bound to the south by a northeast-striking down to the south normal fault (red line). Elongate sinter aprons along this fault indicate it was present before or during sinter deposition. Currently, the majority of high-temperature springs are constrained in a $50 \times 50 \mathrm{~m}$ area east of the left-stepping fault and south of the sinter mounds and depressions.

Reinterpretation of the east-dipping beds in the sandstone/conglomerate unit at the west edge of the area of sinter mounds from a delta front [2] to tilted fault blocks changed the age relations and structural interpretation of Mickey Springs. Taking the 30 kya TL age of the sediments that underlie sinter at Q4 as a minimum age for the sandstone/conglomerate unit, and a total fault offset of $35 \mathrm{~m}$ (from the highest point on the sandstone ridge to the lowest point in the GPR transects) gives a loosely approximated slip rate of $1.2 \mathrm{~mm} /$ year, which is plausible for the area given the slip rate estimates [10] of up to $4 \mathrm{~mm}$ /year. The north-striking faults shown in Figure 5 roughly align with a Quaternary fault shown in Figure 2. The persistent discharge of hot water at the Mickey Springs site for at least 30,000 years may have started at fault tip transfer points on faults shown by J.S. Oldow (fide [15]; Figure 3) but became trapped in this location as faulting occurred on the north-striking, left-stepping normal faults. 
The east-north-east-striking fault added to the map of J.S. Oldow (fide [15]) in Figure 20 follows the slope break between the main area of sinter mounds and broad depressions and the high-temperature area located at lower elevation. Slope-conforming sinter aprons at sinter mounds Q7, Q8, and Q10 (Figure 5) suggest these vents were actively depositing sinter after displacement on the northeast-striking fault generated the topography. Sinter mound Q9 experienced explosive activity reported by Cummings and St. John [2] and between site visits in March and May, 2014 reported by Mowbray [5]. The alignment of four broad depressions (sinter-lined pools) along this trend (Figure 5, D1, D2, D3, and D4) suggest additional faults of this orientation are present where the sinter mounds and broad depressions are concentrated. The parabolic patterns in GPR transects before topographic correction (Figures S1-S4) are consistent with fault zones that serve as conduits for rising hot water.

\subsection{Timeline of Deposits}

A chronology of activity at Mickey Springs is presented in Figure 21. The earliest evidence of silica sinter deposition is clasts of basalt suspended in opaline silica in the sandstone/conglomerate unit. Sedimentary structures, petrified wood, fossils of vascular plants [2], and GPR profiles suggest the basalt-rich sand and gravel were locally sourced (probably Mickey Butte) and deposited on a relatively thin $(\sim 10 \mathrm{~m})$ alluvial fan. This activity was occurring prior to $30 \mathrm{kya}$, but how long before is not known. The most intense silica cementation occurs immediately west of the main sinter mound area (Figure 4). Less intense cementation occurs to the north-northwest and weakly to un-cemented sand and conglomerate forms of low hills immediately north of Mickey Springs on the uplifted side of the north-east-striking fault (Figure 4). Based on the distribution of cementation and sinter, the focus of hot spring activity prior to 30 kya was in the area near modern Mickey Springs. The faults along which hot water rose to the surface have not been identified. However, the conduits were likely controlled by the fault tip intersections of northeast-striking faults. Deformation on the left-stepping north-striking faults that separate the outcrops of the sandstone/conglomerate unit from the area underlain by sinter mounds and sinter-rimmed broad depressions occurred in rocks that had already been silica cemented.

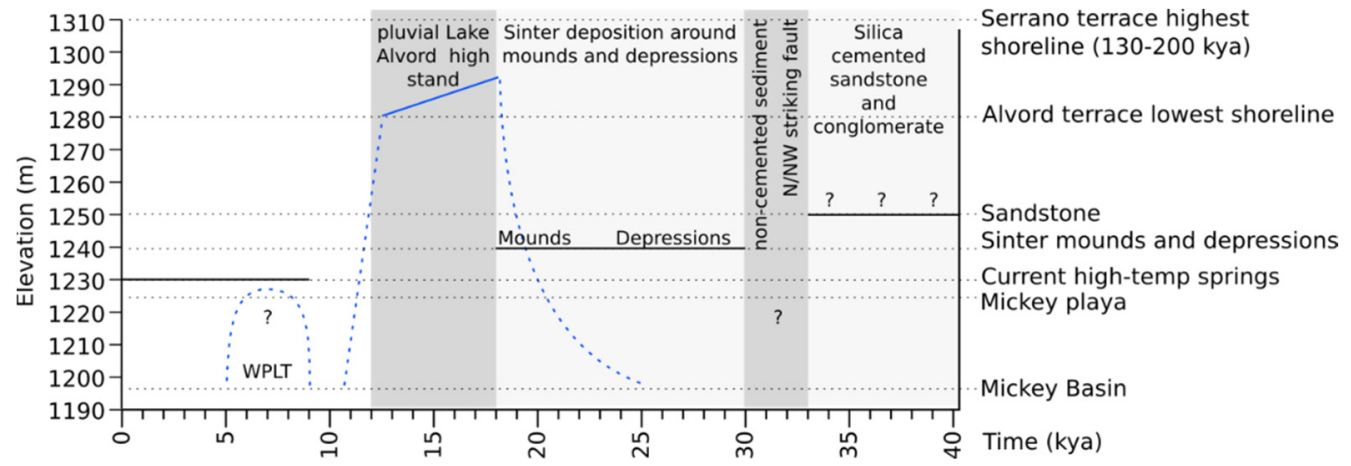

Figure 21. Timeline of major events at Mickey Springs. The scale on the left is the current elevation, and the elevation of relevant features are labeled on the right and indicated by the dashed grey line. The bottom time scale indicates thousands of years before present. The timeline of the hydrothermal activity at Mickey Springs is described in five steps, proceeding from right to left. (1) Silica cementation of sand and conglomerate prior to 30 kya (solid black line). (2) Offsetting of sandstone/conglomerate unit along the N/NW-striking fault, and deposition of uncemented sediments. (3) Deposition of laminar and pool-edge sinter around hot springs from 30 to $18 \mathrm{kya}$ (solid black line). (4) Infilling of springs with lake sediment from pluvial Lake Alvord between 18 and 12 kya. (5) Current high-temperature springs (solid black line) active at lower elevation $(1230 \mathrm{~m}$ ), no sinter deposition, drying of climate to current desert conditions. Hypothesized (blue dashed line) and dated (solid blue line) level of pluvial Lake Alvord, including drying at 12 kya and slight resurgence during presence of Western Pluvial Lakes Tradition (WPLT). 
The lack of cementation in poorly sorted lithic-rich fluvial sediments that directly underlie sinter mounds may suggest a time when sinter was not being deposited or that the vent walls were sealed by silica, preventing cementation in the surrounding sediment. At Borax Lake, the walls of the carrot-shaped 29 -m-deep vent are lined by banded opaline silica, which separates easily eroded fine-grained material of the biomorphic mound from the turbulent waters in the vent $[1-3,59]$. The sinter-rimmed broad depressions are interpreted as forming first. This is suggested by exposures in the walls of Q4, where gently dipping sinter layers interbedded with lithic-rich sand of an apron of a neighboring broad depression underlie more robust wavy sinter and pool-edge sinter of the Q4 sinter mound. The sinter mounds flank the sinter-rimmed broad depressions (Figure 5).

Sinter deposition ceased prior to the onset of pluvial lake conditions. Late Pleistocene pluvial Lake Alvord began to fill as the climate warmed and melted glaciers on Steens Mountain. The lake eventually submerged Mickey Springs. When the elevation of the shoreline coincided with the elevation of the springs, wave action broke the sinter aprons, lodging blocks of sinter in the spring vents. As the depth of water increased, silt- and claysize sediment was deposited in the vents along with minor amounts of sand-size fragments of angular sinter. Most vents had ceased discharging water by this time. However, a few, such as Q4 and Q5, apparently were active while submerged in the lake and flushed the fine-grained sediment from their vents.

As the climate dried and the lake level dropped, wave action again broke blocks of sinter from the pool edges and scattered them on the now filled pool floors. The TL dates for silt- and clay-size sediment within the pools and overlying the sinter aprons are between 18 and 12 kya. The lake sediment was largely eroded either during the receding stage of the lake or by subsequent fluvial activity.

Since the drying of pluvial Lake Alvord, the locations of high-temperature springs, mud pots, and steam vents have emerged in their current location, probably in a zone of extension associated with the southern fault. However, low-volume warm springs are still active within the ancestral vents of the sinter mounds and sinter-rimmed broad depressions.

\section{Conclusions}

Hot springs have been active within a 4-hectare area at Mickey Springs for over 30,000 years and are localized at interacting fault tips of northeast-striking faults as proposed by Anderson and Fairley [15]. Left-stepping north-striking normal faults that separate the area of sinter mounds and broad depressions from the sinter-bearing sandstone/conglomerate unit may have localized up flow to a relatively small area. Movement on an east-northeast-striking normal fault within the area of sinter mounds (Q7, Q8, and Q10) occurred while sinter deposition was active and pre-dates the late Pleistocene rise of lake levels in pluvial Lake Alvord. Evidence of eruptions from the Q9 sinter mound in Figure 12 and [2] suggest this fault continues to be an active zone of up flow.

Silica sinter mounds and broad depressions at Mikey Springs were deposited after 30 kya but prior to late Pleistocene filling of pluvial Lake Alvord, starting at about 18 kya. Coeval deposition of silica sinter and conglomerate occurred before $30 \mathrm{kya}$, but the age is poorly constrained. The biomorphic mound and silica sinter deposits at Borax Lake in the Pueblo Valley were deposited during the Holocene after the drying of pluvial Lake Alvord [3].

Silica sinter at Mickey Springs is 1 to $2 \mathrm{~m}$ thick and overlies un-cemented lithic-rich sand (e.g., Q4, Figure 6). Sinter was no longer being deposited and most springs were inactive when Late Pleistocene water levels were rising in pluvial Lake Alvord. Spring vents and aprons were buried by silt- and clay-sized sediment sourced from melting glaciers on Steens Mountain. Clasts of sinter were buried by the fine-grained sediment. A few vents continued to be active and remained clear of sediments (e.g., Q4 and Q5).

The location of high-temperature springs shifted south to a $50 \times 50 \mathrm{~m}$ area during the Holocene. Calcite deposition, starting where effluent in the outflow channel decreases to $73{ }^{\circ} \mathrm{C}$, and geysering characterize a near-boiling spring. Eruptions from mud pots 
contributed to the construction of a 1.0- to 1.5-m-high berm. A TL date at $40 \mathrm{~cm}$ depth is $9.2 \pm 1$ kya. Sinter-free ejecta from a mud pot sometime between March and May 2014 indicates sinter is not present in the shallow subsurface.

Supplementary Materials: The following are available online at https: / www.mdpi.com/article / 10.3390/en14217186/s1, Figure S1: GPR raw data and topographically corrected data or Track 1, $50 \mathrm{MHz}$. Figure S2: GPR raw data and topographically corrected data for Track 1, $100 \mathrm{MHz}$. Figure S3: GPR raw data and topographically corrected data for Track 2, $50 \mathrm{MHz}$. Figure S4: GPR raw data and topographically corrected data for Track 3, $50 \mathrm{MHz}$.

Author Contributions: Investigation, L.A.M.; Supervision, M.L.C.; Writing-Original draft, L.A.M.; Writing-Review and Editing, M.L.C. and L.A.M. All authors have read and agreed to the published version of the manuscript.

Funding: Part of this research was funded by The Geological Society of America Student Research Award and the Paul Howell Memorial Endowment, Portland State University Foundation for TL dating by David M. Price, University of Wollongong, Australia.

Data Availability Statement: Not applicable.

Acknowledgments: This paper is based on an M.S. thesis by Mowbray completed at Portland State University. Curt Peterson, Adam Booth, and Kenneth Cruikshank provided guidance for GPR, structure from motion, and sensor design, respectively. M. Rudolph, J. Yang, J. McCarley, D. Hansen and D. Eibert provided field assistance in this remote setting. The Burns District Office of the Bureau of Land Management, Burns, Oregon granted permission to conduct research within the Mickey Springs Area of Critical Environmental Concern. David M. Price, University of Wollongong conducted TL dating and provided a discounted price per sample.

Conflicts of Interest: The authors declare no conflict of interest.

\section{Appendix A. TL Dating}

Modified from written communication provided by David M. Price, Thermoluminescence Laboratory, University of Wollongong, Australia.

Thermoluminescence (TL) analysis of the six samples taken from the Mickey Hot Springs area in SE Oregon. In general, the TL characteristics of these samples proved less than ideal, with low TL sensitivity and widely scattered data. The age uncertainties associated with the resultant ages is therefore somewhat greater than that generally recorded.

These samples were analyzed by means of the combined additive and regenerative methods using the 90 to $125 \mu \mathrm{m}$ quartz grain fraction separated by wet sieving and suitable chemical treatment followed by heavy liquid separation. This method provides a means of checking for possible TL sensitivity change due to the laboratory procedure followed. As a modern sample analogue was not available, the TL starting level at the time of final deposition for each sample was assumed to be that reached following a 24-h prepared sample exposure beneath a laboratory ultraviolet lamp (Philips MLU300W). In order to correct for sample aliquot variations, all TL outputs recorded were normalized using a second glow method following a standard irradiation of approximately 19.8 Grays. Each sample analysis utilized 28 sample aliquots in total, eight of these were used to determine the natural TL accumulated since the time of deposition, six to check for sensitivity change, and 14 in the preparation of a TL growth curve to which the mean natural TL value was fitted. By this means, the equivalent radiation dose accumulated since the time of deposition was determined.

The annual radiation dose for each sample was determined by means of thick source alpha counting (TSAC) to determine the uranium- and thorium-specific activity and atomic emission spectroscopy to measure the potassium content. Corrections were made for cosmic radiation, sample rubidium content, and measured sample moisture content. In some cases, the latter value was high, which served to elevate the final ages determined. Sample moisture moderates the radiation received by the sample, thus increasing the age determined by approximately $1 \%$ for each $1 \%$ increase in moisture. 
Sample W4823 The temperature plateau comparison for this sample extended only between 275 and $350{ }^{\circ} \mathrm{C}$ due to low TL sensitivity. This resulted in widely scattered TL data and a larger than usual associated age uncertainty. The more easily reset electron trap level at a temperature of $325^{\circ} \mathrm{C}$ was selected for this sample.

Sample W4828 The sample tube contained a large rock fragment occupying about $50 \%$ of the tube itself. This may have distorted the radiation flux received by the sample undergoing analysis and hence distorting the resultant TL age. If the fragment contains the same uranium, thorium, and potassium as the sediment, then no correction to the final age would be necessary.

Sample W4829 The sample consisted of a loose gritty sand with only a very few, if any, small pebbles. The TL output proved reasonable with a plateau comparison extending between 300 and $500{ }^{\circ} \mathrm{C}$, lending confidence in the final depositional age determined.

Sample W4830 The sample exhibited a reasonable plateau comparison extending between 275 and $450{ }^{\circ} \mathrm{C}$ and similar TL sensitivity as Sample W4829. The ages of these two samples overlap at the one standard deviation level.

Sample W4831 TL sensitivity of this sample was low and there was a violent reaction when treated in hydrofluoric acid possibly due to a high feldspar content. The temperature comparison exhibited by the sample proved shortened and the resultant age of only $0.8 \mathrm{ka}$, the most recent of all samples analyzed but with a large associated age uncertainty.

Sample W4832 TL sensitivity of this sample proved low, and the TL data scattered, leading to a large associated TL age uncertainty.

Table A1. Laboratory results provided by David M. Price, Thermoluminescence Laboratory, University of Wollongong, Australia for TL samples from Mickey Springs, Alvord Valley, Oregon.

\begin{tabular}{lcccccc}
\hline UW Lab Specimen No. & W4832 & W4830 & W4831 & W4823 & W4829 & W4828 \\
\hline Plateau Region $\left({ }^{\circ} \mathrm{C}\right)$ & $275-400$ & $275-450$ & $350-450$ & $275-350$ & $300-500$ & $275-450$ \\
Analysis Temp. $\left({ }^{\circ} \mathrm{C}\right)$ & 375 & 375 & 375 & 325 & 375 & 375 \\
Palaeodose (Grays) & $18.8 \pm 6.4$ & $34.5 \pm 5.8$ & $1.5 \pm 0.9$ & $45.3 \pm 11.7$ & $27.5 \pm 3.1$ & $25.4 \pm 2.7$ \\
K Content $(\%$ by AES) & $1.44 \pm 0.05$ & $1.78 \pm 0.05$ & $1.14 \pm 0.05$ & $1.17 \pm 0.05$ & $1.29 \pm 0.05$ & $1.89 \pm 0.05$ \\
Rb Content (ppm assumed) & $100 \pm 25$ & $100 \pm 25$ & $100 \pm 25$ & $100 \pm 25$ & $100 \pm 25$ & $100 \pm 25$ \\
Moisture Content (\% by weight) & $47.0 \pm 3$ & $32.2 \pm 3$ & $4.1 \pm 3$ & $22.2 \pm 3$ & $34.3 \pm 3$ & $10.1 \pm 3$ \\
Specific Activity (Bq/kg U + Th) & $25.9 \pm 0.7$ & $29.8 \pm 0.9$ & $32.3 \pm 0.9$ & $22.3 \pm 0.6$ & $27.2 \pm 0.9$ & $42.3 \pm 1.1$ \\
Cosmic Contribution & $180 \pm 25$ & $170 \pm 25$ & $168 \pm 25$ & $123 \pm 25$ & $175 \pm 25$ & $170 \pm 25$ \\
( $\mu$ Gy/year assumed) & & & & & & \\
Annual Radiation Dose & $1469 \pm 39$ & $1969 \pm 44$ & $1978 \pm 58$ & $1476 \pm 33$ & $1522 \pm 43$ & $2766 \pm 55$ \\
( $\mu$ Gy/year) & $12.8 \pm 4.4$ & $17.5 \pm 3.0$ & $0.8 \pm 0.5$ & $30.7 \pm 7.9$ & $18.1 \pm 2.1$ & $9.2 \pm 1.0$ \\
TL Age (ka) & & & & &
\end{tabular}

\section{References}

1. St. John, A.M. Hydrogeochemical Characterization of the Alvord Valley Known Geothermal Resources Area, Harney County, Oregon. Master's Thesis, Portland State University, Portland, OR, USA, 1993.

2. Cummings, M.; St. John, A. Hydrogeochemical Characterization of the Alvord Valley Known Geothermal Resources Area (kgra), Harney County, Oregon; Procurement No. De. PR79-91BP19408 and Modification A001, Report prepared for Bonneville Power Administration; Bonneville Power Administration: Portland, OR, USA, 1993.

3. Cummings, M.L.; Wilson, S.D.; St. John, A.M. Borax Lake, a thermal lake confined within a biomorphic mound, Pueblo Valley, Oregon, USA. Palaeogeogr. Palaeoclimatol. Palaeoecol. 2010, 294, 44-55. [CrossRef]

4. Mowbray, L.A.; Cummings, M.L. Supply-limited, climate-driven model for Holocene spring activity at Mickey Springs, Oregon, USA. Geotherm. Resour. Counc. Trans. 2014, 11-18.

5. Mowbray, L.A. Quaternary Chronology and Stratigraphy of Mickey Springs, Oregon. Master's Thesis, Portland State University, Portland, OR, USA, 2015.

6. Scarberry, K.C.; Meigs, A.J.; Grunder, A.L. Faulting in a propagating continental rift: Insight from the late Miocene structural development of the Abert Rim fault, southern Oregon, USA. Tectonophysics 2010, 488, 71-86. [CrossRef]

7. Hemphill-Haley, M.A. Quaternary Stratigraphy and Late Holocene Faulting along the Base of the Eastern Escarpment of Steens Mountain, Southeastern Oregon. Ph.D. Thesis, Humboldt State University, Arcata, CA, USA, 1987.

8. Hemphill-Haley, M.; Page, W.; Burke, R.; Carver, G. Holocene activity of the Alvord fault, Steens Mountain, southeastern Oregon. Woodward Clyde Consult. 1989, prepared for U.S. Geological Survey, Grant No. 14-08-001-G1333. 
9. Singleton, E.S. Late Pleistocene to Holocene Deformation Rates in the Alvord Extensional Basin, Southeastern Oregon, from Ground-Based Lidar Determined Fault Offset of Paleo-Lake Terraces. Ph.D. Thesis, University of Idaho, Moscow, ID, USA, 2005.

10. Oldow, J.S.; Singleton, E.S. Application of terrestrial laser scanning in determining the pattern of late Pleistocene and Holocene fault displacement from the offset of pluvial lake shorelines in the Alvord extensional basin, northern Great Basin, USA. Geosphere 2008, 4, 536-563. [CrossRef]

11. Fairley, J.; Heffner, J.; Hinds, J. Geostatistical evaluation of permeability in an active fault zone. Geophys. Res. Lett. 2003, 30. [CrossRef]

12. Fairley, J.P.; Hinds, J.J. Field observations of fluid circulation patterns in a normal fault system. Geophys. Res. Lett. 2004, 31, L19502. [CrossRef]

13. Fairley, J.P.; Hinds, J.J. Rapid transport pathways for geothermal fluids in an active Great Basin fault zone. Geology 2004, 32, 824-828. [CrossRef]

14. Routh, P.S.; Lyle, M.; Hess, S.; Bradford, J. 3D magnetic characterization of hot springs in a hydrothermal system in the Alvord Basin, Oregon. Geotherm. Resour. Counc. Trans. 2006, 30, 937-940.

15. Anderson, T.R.; Fairley, J.P. Relating permeability to the structural setting of a fault-controlled hydrothermal system in southeast Oregon, USA. J. Geophys. Res. 2008, 113, B05402. [CrossRef]

16. Fournier, R.O.; Rowe, J.J. Solubility of amorphous silica in water at high temperatures and high pressure. Am. Mineral. 1977, 62, 9-10.

17. Rimstidt, J.; Cole, D.R. Geothermal mineralization. 1. the mechanism of formation of the Beowawe, Nevada, siliceous sinter deposit. Am. J. Sci. 1983, 283, 861-875. [CrossRef]

18. Cady, S.; Farmer, J. Fossilization processes in siliceous thermal springs: Trends in preservation along thermal gradients. In Ciba Foundation Symposium 202-Evolution of Hydrothermal Ecosystems on Earth (and Mars?); Bock, G., Goode, J., Eds.; Wiley: Chichester, UK, 1996; pp. 150-173.

19. Preston, L.J.; Benedix, G.K.; Genge, M.J.; Sephton, M.A. A multidisciplinary study of silica sinter deposits with applications to silica identification and detection of fossil life on Mars. Icarus 2008, 198, 331-350. [CrossRef]

20. Wu, C. Visualsfm: A Visual Structure from Motion System. 2011, a Software Package for Structure from Motion, Creating Dense Point Construction from photographs. Available online: http:/ / ccwu.me/vsfm (accessed on 10 June 2014).

21. Cignoni, P.; Ranzuglia, G. Meshlab v1.3.3. 2014 an Open Source Program for Editing Points and Triangulated Meshes. Available online: http:/ / meshlab.sourceforge.net (accessed on 10 June 2014).

22. Girardeau-Montaut, D. Cloudcompare, v2.4. 2012 Open Source Software for 3D Point Cloud and Mesh Processing. Available online: http:/ / www.cloudcompare.org/ (accessed on 4 December 2013).

23. Sensors and Software, Ekko View Deluxe, v.1.4. 2009 Proprietary Software for Visualizing GPR Data. Available online: http: / / www.sensoft.ca/ (accessed on 25 May 2014).

24. Hooper, P.; Binger, G.; Lees, K. Ages of the Steens and Columbia River flood basalts and their relationship to extension-related calc-alkalic volcanism in eastern Oregon. Geol. Soc. Am. Bull. 2002, 114, 43-50. [CrossRef]

25. Moore, N.E.; Grunder, A.L.; Bohrson, W.A. The three-stage petrochemical evolution of the Steens Basalt (southeast Oregon, USA) compared to large igneous provinces and layered mafic intrusions. Geosphere 2018, 14, 2505-2532. [CrossRef]

26. Walker, G.; Repenning, C. Reconnaissance Geologic Map of the Adel Quadrangle, Lake, Harney, and Malheur Counties, Oregon; U.S. Geological Survey Map I-466, 1965, scale 1:250,000; U.S. Geological Survey: Reston, VA, USA.

27. Bradford, J.H.; Liberty, L.M.; Lyle, M.W.; Clement, W.P.; Hess, S. Imaging complex structure in shallow seismic-reflection data using prestack depth migration. Geophysics 2006, 71, B175-B181. [CrossRef]

28. Wisian, K.W.; Blackwell, D.D. Numerical modeling of Basin and Range geothermal systems. Geothermics 2004, 33, 713-741. [CrossRef]

29. McKenna, J.R.; Blackwell, D.D. Numerical modeling of transient Basin and Range extensional geothermal systems. Geothermics 2004, 33, 457-476. [CrossRef]

30. Blackwell, D.D.; Hull, D.; Bowen, R.; Steele, J. Heat Flow of Oregon, Oregon; Department of Geology and Mineral Industries: Portland, OR, USA, 1978.

31. Catchings, R. Seismic implications for crustal composition and deformation along the Basin and Range/Cascade Range boundary. Am. Geophys. Union Trans. 1990, 71, 1613.

32. Cleary, J.G. Geothermal Investigation of the Alvord Valley, Southeast Oregon. Master's Thesis, University of Montana, Missoula, MT, USA, 1976.

33. Benson, L.; Thompson, R. Lake-level variation in the Lahontan basin for the past 50,000 years. Quat. Res. 1987, 28, 69-85. [CrossRef]

34. Smith, G.I.; Stuiver, M. Subsurface Stratigraphy and Geochemistry of Late Quaternary Evaporites, Searles Lake, California; U.S. Geological Survey Professional Paper 1043; 1979. Available online: https://pubs.er.usgs.gov/publication/pp1043 (accessed on 10 October 2021).

35. Kurth, G.; Phillips, F.M.; Reheis, M.C.; Redwine, J.L.; Paces, J.B. Cosmogenic nuclide and uranium-series dating of old high shorelines in the western Great Basin, USA. Geol. Soc. Am. Bull. 2011, 123, 744-768. [CrossRef]

36. Carter, D.T.; Ely, L.L.; O'Connor, J.E.; Fenton, C.R. Late Pleistocene outburst flooding from pluvial lake Alvord into the Owyhee River, Oregon. Geomorphology 2006, 75, 346-367. [CrossRef] 
37. Personius, S.F.; Crone, A.J.; Machette, M.N.; Kyung, J.B.; Cisneros, H.; Lidke, D.J.; Mahan, S.A. Trench Logs and Scarp Data from an Investigation of the Steens Fault Zone, Bog Hot Valley and Pueblo Valley, Humboldt County, Nevada. 2006. Available online: http:/ / pubs.usgs.gov/sim/2006/2952/ (accessed on 15 June 2014).

38. Pettigrew, R.M. Prehistoric human land-use patterns in the Alvord basin, southeastern Oregon. J. Calif. Great Basin Anthropol. 1984, 61-90.

39. Negrini, R.M. Pluvial lake sizes in the northwestern Great Basin throughout the Quaternary period: Great Basin aquatic systems history. Smithson. Contrib. Earth Sci. 2002, 33, 11-52.

40. Bedwell, S.F. Fort Rock Basin: Prehistory and Environment; University of Oregon Press: Eugene, OR, USA, 1973.

41. Beck, C. Steens Mountain Surface Archaeology: The Sites. Ph.D. Thesis, University of Washington, Seattle, WA, USA, 1984.

42. Western Regional Climate Center, Desert Research Institute. Period of Record Monthly Climate Summary for Fields, Oregon, Station id 352876 (5/1/73 to 3/31/2013). Available online: http:/ / www.wrcc.dri.edu/cgi-bin/cliMAIN.pl?or2876 (accessed on 5 May 2014).

43. United States Geological Survey. Available online: http:/ / earthquake.usgs.gov/hazards/qfaults/ (accessed on 15 June 2014).

44. Oregon Department of Geology and Mineral Industries. Available online: http://www.oregongeology.org/arcgis/rest/services/ Public (accessed on 15 June 2014).

45. Echelle, A.A.; Echelle, A.F. Restoration of aquatic habitats and native fishes in the desert some successes in western North America. In Standing between Life and Extinction: Ethics and Ecology of Conserving Aquatic Species in North American Deserts; Propst, D., Williams, J., Bestgen, K., Hoagstrom, C., Eds.; The University of Chicago Press: Chicago, IL, US, 2020; pp. 353-374.

46. Oestreicher, Z.W.J. Geomicrobiology Investigation of Mickey Hot Springs, Southeastern Oregon. Master's Thesis, Portland State University, Portland, OR, USA, 2004.

47. Nicholson, K.N.; Link, K.N.; Garringer, L. Relative ages of the Borax Lake and Mickey geothermal systems, Alvord basin, Oregon USA: Preliminary evidence from silica phase transitions. In Proceedings of the 26th New Zealand Geothermal Workshop, Taupo, New Zealand, 31 January-3 February 2004; pp. 40-45.

48. Curewitz, D.; Karson, J.A. Structural settings of hydrothermal outflow: Fracture permeability maintained by fault propagation and interaction. J. Volcanol. Geotherm. Res. 1997, 79, 149-168. [CrossRef]

49. Cummings, M.L.; St John, A.M.; Sturchio, N.C. Hydrogeochemical characterization of the Alvord basin geothermal area, Harney County, Oregon, USA. In Proceedings of the 15th New Zealand Geothermal Workshop, Auckland, New Zealand, 1993; pp. 119-124. Available online: https://www.geothermal-energy.org/pdf/IGAstandard/NZGW/1993/Cummings.pdf (accessed on 10 October 2021).

50. St. John, A.; Cummings, M.L. Silica sinter deposits and recent geysering activity at Mickey Hot Springs, Alvord Valley, Harney County, Oregon. Geol. Soc. Am. Abstr. Programs 1992, 24, 82.

51. Cross, J. Mickey Hot Springs, Harney County, Oregon-Observations of 27-29 March 1992: The Geyser Observation and Study Association Transactions IV. 1993, pp. 212-219. Available online: https://www.gosa.org/transactions.aspx (accessed on 10 October 2021).

52. Kipple, M.J. Temperature patterns and increase of surface activity at Mickey Hot Springs, Oregon. Geol. Soc. Am. Abstr. Programs 2017, 49. [CrossRef]

53. Kipple, M.J. If a spring erupts, and no one is there to hear it ... The eruptive Features of Mickey Hot Springs, Oregon. Geyser Gazer Sput 2017, 37, 6-8.

54. Dougherty, A.; Lynne, B. Utilizing ground penetrating radar to image vents and fractures in geothermal environments. Am. Geophys. Union Fall Meet. Abstr. 2010, 2010, 2358.

55. Lynne, B.; Dougherty, A. Ground penetrating radar successful in imaging hot spring deposits: A new geothermal exploration tool. Am. Geophys. Union Fall Meet. Abstr. 2010, 2010, V23D-06.

56. Lynne, B.Y.; Sim, C.Y. Ground penetrating radar and its successful application in imaging USA and New Zealand siliceous sinters. In Proceedings of the New Zealand Geothermal Workshop, Auckland, New Zealand, 19-21 November 2012.

57. Jaworowski, C.; Lynne, B.Y.; Heasler, H.; Foley, D.; Smith, I.J.; Smith, G.A. Detecting natural fractures with ground penetrating radar and airborne night-thermal imaging around Old Faithful Geyser, Yellowstone National Park, USA. Geothermics 2020, 85. [CrossRef]

58. Wilson, S.D. Geology and Slope Stability of the Borax Lake Hydrothermal Mound, Alvord Basin, Oregon. Master's Thesis, Portland State University, Portland, OR, USA, 2000.

59. Schneider, T.R.; McFarland, W.D. Hydrologic Data and Description of a Hydrologic Monitoring Plan for the Borax Lake area, Oregon. Open-File Report 95-367; 1995. Available online: https://pubs.er.usgs.gov/publication/ofr95367 (accessed on 10 October 2021). 